\title{
МАГМАТИЗМ И ЭПИТЕРМАЛЬНОЕ Ag-АИ ОРУДЕНЕНИЕ КРАСНОЯРСКОГО РУДНОГО ПОЛЯ ГОРНОГО АЛТАЯ
}

\author{
Гусев Анатолий Иванович', \\ anzerg@mail.ru
}

Табакаева Евгения Михайловна', tabakaeva16@mail.ru

\author{
' Алтайский государственный гуманитарно-педагогический университет имени В.М. Шукшина, \\ Россия, 659333, г. Бийск, ул. Владимира Короленко, 53.
}

\begin{abstract}
Актуальность исследования определяется необходимостью освещения новых данных по петрологии, геохимии субвулканических пород и эпитермальному Ag-Аи оруденению Красноярского рудного поля Горного Алтая. С субвулканическими штоками гранитоидов пространственно и парагенетически связаны различные типы оруденения: меди, кобальта, мышьяка, вольфрама и золота. Впервые для Горного Алтая исследован высоко-серный тип Ag-Аu оруденения.

Цель исследования: изучить петрологические, геохимические особенности пород и оруденения Красноярского месторождения с использованием экспериментальных диаграмм, позволяющих выявлять генетические проблемы и физико-химические особенности петро-рудогенезиса.

Методы исследования включали изучение состава горных пород с применением лазерно-абляционного анализа методом индуктивно-связанной плазмы на спектрометре «ОРТІМА\&4300» с высокой чувствительностью определения элементов в Лаборатории Института минералогии, геохимии и кристаллохимии редких элементов (г. Москва). Изотопный состав серы и кислорода определён на масс-спектрометре МИ 1201в в той же лаборатории.

Результаты. Главными рудогенерирующими объектами в Красноярском рудном поле являются субвулканические штоки гранитоидов среднего девона коргонского комплекса, которые относятся к пералюминиевому типу с варьирующими характеристиками по магнию и железу. В породах проявлен тетрадный эффект фракционирования P3Э W-типа. Концентрации Au и Ag в породах увеличиваются с уменьшением величины тетрадного эффекта фракционирования PЗЭ W-типа. Глубинный магматический очаг эволюционировал в сторону повышения его уровня с формированием резко кислотно-серных характеристик и формированием околорудных аргиллизитов. Оруденение Красноярского месторождения представлено серией сближенных кварцевых жил, с образованием своеобразного линейного штокверка. Руды сформированы в три стадии: существенно сульфидную, теллуридную и пострудную. Основные рудные минералы: пирит, галенит, сфалерит, тетраэдрит, теннантит, электрум, тетрадимит, редко - алтаит, гессит, энаргит, люцонит. Основные жильные минералы: кварц, кальцит, хлорит, сидерит, каолинит, монтмориллонит, иллит. Концентрации золота в рудах варьируют от 0,5 до 29,6 г/T, серебра - от 15 до 5000 г/т. Соотношение Ag/Aи в рудах варьирует от 135 до 150 и позволяет относить Красноярское месторождение к Ag-Аи типу. Температуры гомогенизации газово-жидких включений в кварце разных генераций от стадии к стадии снижались от 265 до $175{ }^{\circ} \mathrm{C}$. Фугитивность серы снижалась от первой стадии (-10-11) ко второй (-15-16), f Те повышалась от $(-15)$ до (-10) и f O от $(-39,5)$ до (-37). Изотопы серы и кислорода свидетельствуют о магматогенном источнике серы и метеорном - кислорода.
\end{abstract}

\section{Ключевые слова}

Геохимия, петрология, гранитоиды, штоки, тетрадный эффект фракционирования РЗЭ, жилы, свинец, медь, золото, серебро, фугитивность $\mathrm{S}_{2}, \mathrm{O}_{2}$, $\mathrm{Te}_{2}$.

\section{Введение}

Эпитермальное Ag-Au оруденение занимает значительной объём в добыче серебра и золота, составляя для золота более $17 \%$, для серебра более $6 \%$ мировой добычи [1]. На Алтае такой тип оруденения также получил распространение. Одним из интереснейших объектов, который отрабатывается в настоящее время, является Суричское месторождение, расположенное на западе Алтайского края. Оно относится к низко-серному (low sulfidation) типу [2]. Красноярское месторождение относится $\kappa$ другому типу эпитермальных систем высоко-серному (high-sulfidation). $\mathrm{K}$ этому типу относятся такие известные гигантские $\mathrm{Ag}-\mathrm{Au}$ месторождения, как Голдфилд (Невада, США), Лепанто (Филиппины), Ивато (Япония). Развитие сырьевой базы золота и серебра на Алтае весьма актуально, и изучение Красноярского месторождения обеспечит новый тип эпитермальных $\mathrm{Ag}-\mathrm{Au}$ и порфировых $\mathrm{Cu}-\mathrm{Au}$ систем региона.

\section{Субвулканические породы}

\section{Красноярского рудного поля}

В пределах Красноярского рудного поля среди вулканитов коргонской свиты $\left(\lambda \pi \mathrm{D}_{2} \mathrm{krg}_{2}\right)$ выявлены два небольших субвулканических штока, сложенных преимущественно плагиогранит-порфирами и плагиолейкогранит-порфирами (рис. 1). Западное субвулканическое тело имеет размеры $500 \times 200$ м, восточное $-450 \times 100$ м. Они имеют субсогласное залегание, и в их экзоконтактовых частях локализуются проявления меди, свинца и Красноярское месторождение золота. Штоки и проявления меди, свинца, цинка, урана, мышьяка, вольфрама контролируются зонами субширотных разломов сбросо-сдвиговой кинематики. Породы указанных штокообразных тел характеризуются плохой гомогенизацией и неравномерной раскристаллизацией слагающих их минералов. Нередки шлиры темноцветных минералов удлинённой овальной формы размерами от 1,5 до 2,5 см. Как 
правило, породы имеют порфировую структуру с размерами вкрапленников кварца и полевого шпата от 1,5 до 2,5 мм, а также микрографическую структуру основной ткани породы. В краевой фации нередки переходы в фельзиты и фельзит-порфиры. В краевой части более крупного западного штока отмечены также фрагменты гранодиоритпорфиров размерами от 1,5 до 3,2 м в поперечнике.

Преобладающие плагиогранит-порфиры и плагиолейкогранит-порфиры сложены альбитом, олигоклазом (55-65\%), кварцем (30-44\%), иногда присутствует биотит, мусковит и наложенный слабо-решетчатый микроклин (до 6 \% ). Во вкрапленниках плагиоклаз преобладает над кварцем. Акцессорные минералы представлены сфеном, апатитом, магнетитом, цирконом, редко - монацитом, ильменитом, турмалином. Химический состав субвулканических пород характеризуется высокой натриевостью $\left(\mathrm{Na}_{2} \mathrm{O}=4,2-6,55 \%\right)$, глиноземистостью (индекс Шенда $=1,06-1,08)$ и низкой калиевостью $\left(\mathrm{K}_{2} \mathrm{O}=0,3-1,17 \%\right)$. Низкое уран-ториевое отношение (менее 1) в породах указывает на сравнительно неизменённый состав пород с отсутствием наложенных вторичных процессов. Из микро- элементов повышенными концентрациями отличаются $\mathrm{Sc}, \mathrm{Zr}, \mathrm{Au}, \mathrm{Ag}$, сумма РЗЭ, а в некоторых породах - Pd и $\mathrm{Pt}$ (табл. 1). Наблюдается некоторая деплетированнось пород высоко-зарядными элементами $\mathrm{Nb}, \mathrm{Ti}, \mathrm{Ta}$, а также элементами с большим ионным радиусом ( $\mathrm{K}, \mathrm{Rb}, \mathrm{Cs}, \mathrm{Pb})$. По нормированным отношениям к хондриту $\left(\mathrm{La} / \mathrm{Yb}_{\mathrm{N}}\right.$ и $\mathrm{La} / \mathrm{Sm}_{\mathrm{N}}$ ) можно заключить о значительном дифференцированном типе распределения РЗЭ в породах. В целом субвулканические образования характеризуются повышенными концентрациями и мантийных, и коровых элементов, указывая на мантийно-коровое взаимодействие при их генерации. Отношение $\mathrm{Eu} / \mathrm{Eu}^{*}$ в породных типах менее 1 , что ниже хондритовых значений. Сумма РЗЭ в них варьирует в значительных пределах от 144,1 до 349,2 и в целом указывает на обогащённость лантаноидами.

На канонических диаграммах фигуративные точки составов пород локализуются в поле пералюминиевых разностей, а также магнезиальных и железистых разновидностей со значительными вариациями соотношений железа и магния в породах (рис. 2).
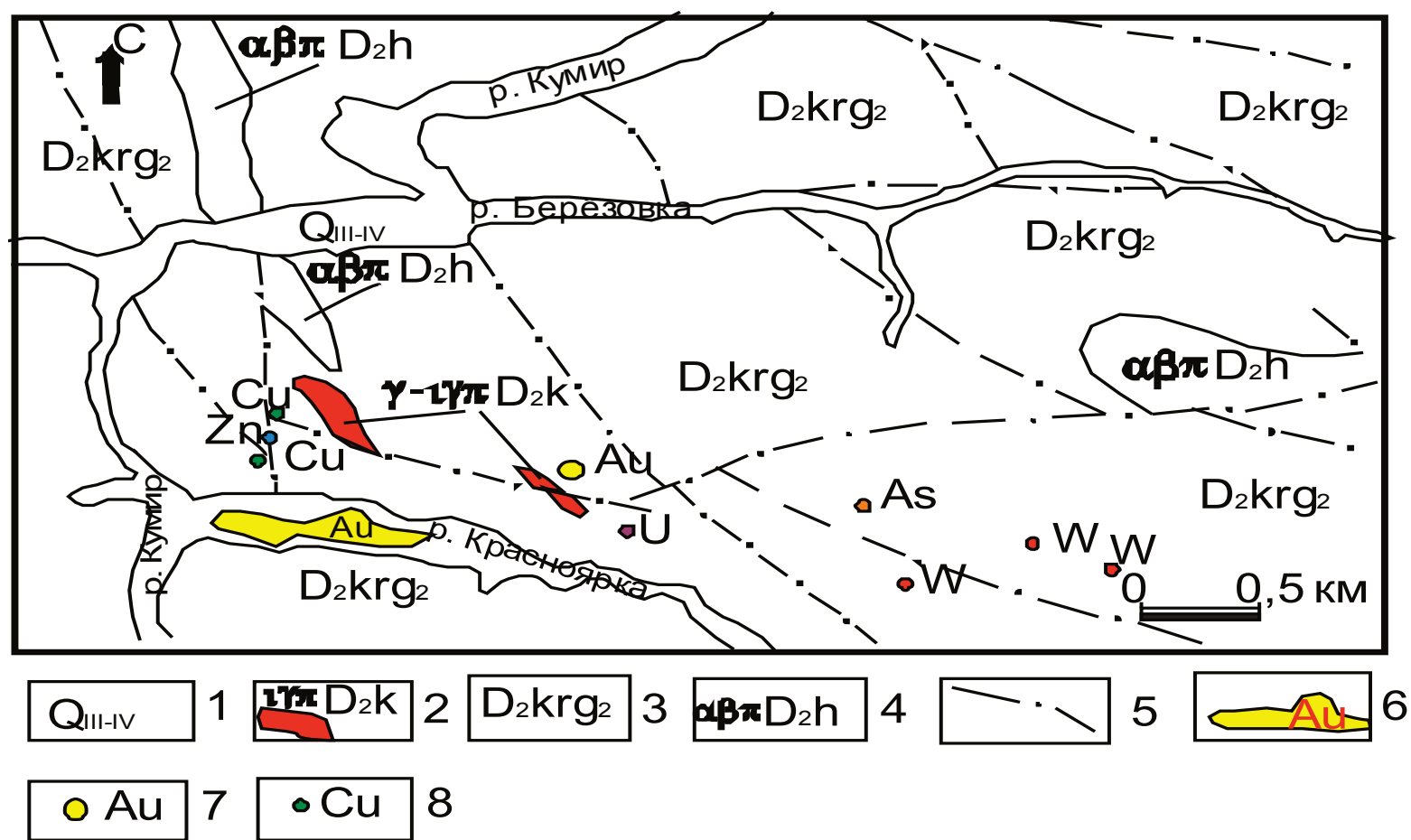

Рис. 1. Схематическая карта полезных ископаемых Красноярского рудного поля (составлена авторами с учётол данных В.В. Миронова ): 1 - современные аллювиальные образования; 2 - субвулканические плагиогранит-порфиры и плагиолейкогранит-порфиры коргонского комплекса; 3 - туфы, лавы, игнимбриты риолитов коргонской свиты; 4 - андезибазальтовые порфириты холзунской свиты; 5 - разломы; 6 - Красноярская россыпь золота; 7 - Красноярское месторождение золота; 8 - проявления (леди, свинца, цинка, мышьяка, урана, вольфрала)

Fig. 1. Schematic map of mineral resources of Krasnoyarsk ore field (composed by the authors considering the data of V.V. Mironov): 1 are the modern alluvial deposits; 2 are the subvolcanic plagiograniteporphyres and plagioleucogranite-porphyres of Korgon complex; 3 are the tuffs, lava, ignimbrites of rhyolites of Korgonsk suite; 4 are the basaltic andesite porphyrites of Kholzunskaya suite; 5 are the faults; 6 is the Krasnoyarsk placer of gold; 7 is the Krasnoyarsk deposit of gold; 8 are the manifestations (copper, lead, zinc, arsenic, uranium, tunstain) 
Таблица 1. Содержания оксидов (масс. \%) и микроэлементов $($ (г/m) в субвулканических породах коргонского комплекса Красноярского рудного поля

Table 1. Contents of oxides (wt.\%) and microelements (ppm) in subvolcanic rocks of Korgonsk complex of Krasnoyarsk ore field

\begin{tabular}{|c|c|c|c|c|c|c|c|c|c|}
\hline $\begin{array}{c}\text { Компо- } \\
\text { ненты } \\
\text { Com- } \\
\text { ponents }\end{array}$ & 1 & 2 & 3 & 4 & 5 & 6 & 7 & 8 & 9 \\
\hline $\mathrm{SiO}_{2}$ & 65,6 & 70,2 & 72,2 & 73,11 & 73,71 & 73,82 & 74,08 & 74,23 & 75,9 \\
\hline $\mathrm{TiO}_{2}$ & 0,77 & 0,69 & 0,43 & 0,42 & 0,51 & 0,49 & 0,44 & 0,38 & 0,23 \\
\hline $\mathrm{Al}_{2} \mathrm{O}_{3}$ & 13,6 & 13,8 & 14,7 & 13,74 & 12,9 & 13,75 & 14,3 & 14,2 & 13,5 \\
\hline $\mathrm{Fe}_{2} \mathrm{O}_{3}$ & 4,6 & 2,9 & 1,45 & 1,1 & 1,06 & 0,85 & 1,56 & 1,4 & 1,59 \\
\hline $\mathrm{FeO}$ & 2,9 & 1,9 & 1,03 & 0,94 & 0,99 & 0,5 & 0,9 & 0,8 & 1,1 \\
\hline $\mathrm{MnO}$ & 0,16 & 0,13 & 0,14 & 0,14 & 0,15 & 0,14 & 0,13 & 0,13 & 0,13 \\
\hline $\mathrm{MgO}$ & 0,9 & 1,55 & 0,97 & \begin{tabular}{|l|}
0,67 \\
\end{tabular} & 1,23 & 0,63 & 1,24 & 0,97 & 0,63 \\
\hline $\mathrm{CaO}$ & 1,2 & 0,47 & 1,6 & 2,6 & 1,03 & 1,95 & 0,34 & 0,6 & 0,12 \\
\hline $\mathrm{Na}_{2} \mathrm{O}$ & 5,95 & 4,2 & 5,65 & 5,15 & 5,04 & 6,55 & 5,5 & 5,6 & 6,25 \\
\hline $\mathrm{K}_{2} \mathrm{O}$ & 0,7 & 2,4 & 0,73 & 1,17 & 0,74 & 0,43 & 0,7 & 0,75 & 0,3 \\
\hline $\mathrm{P}_{2} \mathrm{O}_{5}$ & 0,15 & 0,12 & 0,1 & 0,09 & 0,1 & 0,08 & 0,06 & 0,06 & 0,03 \\
\hline $\begin{array}{l}\text { П.П.П. } \\
\text { LOI }\end{array}$ & 0,9 & 1,2 & 0,4 & 0,3 & 0,2 & 0,3 & 0,3 & 0,4 & 0,3 \\
\hline $\begin{array}{l}\text { Сумма } \\
\text { Sum }\end{array}$ & 99,8 & 99,8 & 99,4 & 100,1 & 100,1 & 100,3 & 99,9 & 100,2 & 100,4 \\
\hline V & 9,0 & 8,5 & 1,5 & 2,0 & 1,6 & 1,8 & 1,7 & 0,2 & 8,0 \\
\hline $\mathrm{Cr}$ & 4,1 & 2,6 & 1,5 & 1,0 & 1,4 & 1,6 & 2,0 & 2,5 & 2,2 \\
\hline $\mathrm{Ba}$ & 424 & 256 & 185 & 400 & 120 & 118 & 70 & 19 & 170 \\
\hline $\mathrm{Ni}$ & 5,8 & 2,6 & 1,9 & 1,7 & 1,5 & 1,6 & 1,3 & 1,4 & 2,0 \\
\hline Co & 4,8 & 1,9 & 1,8 & 1,6 & 1,4 & 1,7 & 1,1 & 1,0 & 3,0 \\
\hline $\mathrm{Cu}$ & 10,8 & 2,6 & 2,5 & 2,2 & 2,1 & 1,9 & 0,9 & 0,4 & 9,0 \\
\hline $\mathrm{Zn}$ & 18,3 & 9,2 & 3,6 & 3,2 & 3,0 & 2,6 & 0,9 & 0,3 & 9,1 \\
\hline $\mathrm{Pb}$ & 8,9 & 7,9 & 7,1 & 7,0 & 6,3 & 5,5 & 4,4 & 3,4 & 3,5 \\
\hline $\mathrm{Sn}$ & 2,1 & 2,8 & 1,2 & 1,3 & 1,1 & 1,0 & 0,9 & 1,1 & 2,0 \\
\hline Sc & 76 & 53 & 55 & 58 & 72 & 70 & 76 & 75 & 9,9 \\
\hline $\mathrm{Sr}$ & 245 & 256 & 260 & 270 & 210 & 220 & 115 & 97 & 12,5 \\
\hline $\mathrm{Zr}$ & 163 & 176 & 180 & 200 & 198 & 165 & 180 & 156 & 181 \\
\hline $\mathrm{Nb}$ & 13,8 & 12,9 & 10 & 10,1 & 10,3 & 9,5 & 9,8 & 9,7 & 9,2 \\
\hline $\mathrm{Y}$ & 30,4 & 30,6 & 29,2 & 35,8 & 35,3 & 33,1 & 31,9 & 28,8 & 35,5 \\
\hline $\mathrm{Yb}$ & 3,7 & 2,3 & 5,2 & 5,0 & 5,1 & 4,9 & 4,9 & 4,9 & 5,2 \\
\hline $\mathrm{U}$ & 2,2 & 1,8 & 1,1 & 1,0 & 0,9 & 1,2 & 1,3 & 1,2 & 2 \\
\hline Th & 7,9 & 9,5 & 10,1 & 11,2 & 9,7 & 12,1 & 13,2 & 13,1 & 8,5 \\
\hline $\mathrm{Li}$ & 0,9 & 2,9 & 2,5 & 2,61 & 2,58 & 2,14 & 1,95 & 0,77 & 3,2 \\
\hline $\mathrm{Be}$ & 6,5 & 5,7 & 5,5 & 1,7 & 0,6 & 11,1 & 15,5 & 11,4 & 10,8 \\
\hline W & 1,8 & 2,6 & 1,0 & 1,2 & 1,3 & 1,2 & 1,3 & 0,8 & 1,6 \\
\hline Mo & 1,6 & 1,8 & 0,9 & 1,1 & 1,3 & 0,8 & 0,7 & 1,0 & 2,1 \\
\hline $\mathrm{Rb}$ & 34 & 46 & 24 & 45 & 30 & 15 & 21 & 19 & 11,0 \\
\hline $\mathrm{Cs}$ & 4,1 & 2,3 & 3,5 & 3,5 & 4,1 & 4,2 & 4,8 & 4,2 & 8,4 \\
\hline $\mathrm{Ga}$ & 15,9 & 14,8 & 15,1 & 14,2 & 19,3 & 17 & 16,3 & 17,2 & 16,3 \\
\hline $\mathrm{La}$ & 22,4 & 23,5 & 95 & 97,2 & 99 & 98 & 94 & 100,6 & 101,3 \\
\hline $\mathrm{Ce}$ & 45,5 & 43,7 & 115 & 118 & 114,2 & 116 & \begin{tabular}{|l|}
113 \\
\end{tabular} & 117 & 118 \\
\hline $\operatorname{Pr}$ & 4,1 & 4,8 & 5,5 & 5,6 & 5,7 & 6,0 & 4,9 & 5,8 & 6,1 \\
\hline $\mathrm{Nd}$ & 17,8 & 18,3 & 49,7 & 50,0 & 50,6 & 50,9 & 49,8 & 51,8 & 52,1 \\
\hline $\mathrm{Sm}$ & 3,9 & 5,4 & 9,9 & 10,1 & 10,3 & 10,2 & 9,7 & \begin{tabular}{|l|}
10,1 \\
\end{tabular} & 11,9 \\
\hline $\mathrm{Eu}$ & 1,45 & 0,96 & 1,3 & 1,5 & 1,4 & 1,6 & 1,62 & 1,55 & 1,5 \\
\hline Gd & 6,2 & 5,9 & 7,3 & 7,2 & 7,5 & 7,4 & 7,3 & \begin{tabular}{|l|}
7,56 \\
\end{tabular} & 7,6 \\
\hline $\mathrm{Tb}$ & 0,9 & 0,74 & 1,1 & 1,2 & 1,25 & 1,32 & 1,18 & 1,32 & 1,4 \\
\hline Dy & 1,1 & 0,9 & 0,8 & 0,9 & 0,85 & 0,91 & 0,64 & 0,6 & 0,7 \\
\hline Ho & 3,5 & 3,4 & 3,5 & 3,6 & 3,4 & 3,7 & 3,6 & 3,8 & 4,0 \\
\hline Er & 0,8 & 0,73 & 0,7 & 0,66 & 0,7 & 0,8 & 0,83 & 0,8 & 0,9 \\
\hline $\mathrm{Tm}$ & 2,1 & 2,0 & 2,1 & 2,2 & 2,3 & 2,2 & 2,0 & 2,3 & 2,5 \\
\hline $\mathrm{Lu}$ & 0,29 & 0,35 & 0,3 & \begin{tabular}{|l|}
0,33 \\
\end{tabular} & 0,4 & \begin{tabular}{|l|}
0,41 \\
\end{tabular} & \begin{tabular}{|l|}
0,37 \\
\end{tabular} & 0,4 & 0,45 \\
\hline $\mathrm{Hf}$ & 4,97 & 3,9 & 6,2 & 6,1 & 6,3 & 6,8 & 6,5 & 5,8 & 6,0 \\
\hline $\mathrm{Ta}$ & 0,55 & 0,65 & 0,5 & 0,52 & 0,54 & 0,6 & 0,63 & \begin{tabular}{|l|}
0,62 \\
\end{tabular} & 0,7 \\
\hline $\mathrm{Au}$ & 0,01 & 0,01 & 0,04 & \begin{tabular}{|l|}
0,05 \\
\end{tabular} & 0,05 & \begin{tabular}{|l}
0,07 \\
\end{tabular} & 0,1 & \begin{tabular}{|l|}
0,09 \\
\end{tabular} & 0,08 \\
\hline $\mathrm{Ag}$ & 3,1 & 3,5 & 6,8 & 8,1 & 8,2 & 10,3 & 11,6 & 11,1 & 10,3 \\
\hline $\mathrm{Sb}$ & 0,15 & 0,11 & 0,1 & 0,1 & 0,1 & 0,18 & 0,2 & 0,25 & 0,19 \\
\hline $\mathrm{Ge}$ & 1,6 & 1,1 & 1,2 & 1 & 1,1 & 1,3 & 1,4 & 1,5 & 1,6 \\
\hline
\end{tabular}

Окончание табл. 1

Table 1

\begin{tabular}{|c|c|c|c|c|c|c|c|c|c|}
\hline 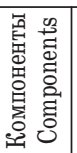 & 1 & 2 & 3 & 4 & 5 & 6 & 7 & 8 & 9 \\
\hline $\mathrm{Ru}$ & - & $<0,002$ & - & \begin{tabular}{|l|}
$<0,002$ \\
\end{tabular} & $<0,002$ & $<0,002$ & - & $<0,002$ & $<0,002$ \\
\hline $\mathrm{Rh}$ & - & $<0,002$ & - & \begin{tabular}{|c|}
$<002$ \\
\end{tabular} & $<0,002$ & $<0,002$ & - & $<0,002$ & $<0,002$ \\
\hline $\mathrm{Pd}$ & 0,006 & 0,0067 & - & 0,0059 & 0,0034 & 0,0056 & 0,007 & $<0,002$ & $<0,002$ \\
\hline $\mathrm{Ir}$ & - & $<0,002$ & - & $<0,002$ & $<0,002$ & $<0,002$ & - & $<0,002$ & $<0,002$ \\
\hline $\mathrm{Pt}$ & 0,007 & $<0,002$ & - & \begin{tabular}{|l|}
0,0051 \\
\end{tabular} & $<0,002$ & $<0,002$ & 0,007 & $<0,002$ & $<0,002$ \\
\hline$\Sigma \mathrm{REE}$ & 144,1 & 144,6 & 326,6 & 339,3 & 330,9 & 337,4 & 325,7 & 337,3 & 349,2 \\
\hline $\begin{array}{c}\mathrm{La} / \\
\mathrm{YbN}\end{array}$ & 3,99 & 6,72 & 12,1 & 12,75 & 12,76 & 13,18 & 12,5 & 13,68 & 12,78 \\
\hline $\begin{array}{c}\mathrm{La} / \\
\mathrm{SmN}\end{array}$ & 3,52 & 2,7 & 5,9 & 5,9 & 5,8 & 5,9 & 5,9 & 6,1 & 5,2 \\
\hline $\begin{array}{l}\mathrm{Eu} / \\
\mathrm{Eu}\end{array}$ & 0,91 & 0,52 & 0,45 & 0,52 & 0,47 & 0,54 & 0,57 & 0,53 & 0,46 \\
\hline $\mathrm{U} / \mathrm{Th}$ & 0,28 & 0,19 & 0,10 & \begin{tabular}{|l|}
0,089 \\
\end{tabular} & \begin{tabular}{l|}
0,093 \\
\end{tabular} & \begin{tabular}{|l|}
0,099 \\
\end{tabular} & 0,09 & 0,092 & 0,23 \\
\hline
\end{tabular}

Прилечание. П.П.П. - потери при прокаливании; $N$ - элементы нормированы по [3]. Eu*=(Sm, $\left.+G d_{\mathrm{N}}\right) / 2$. Субвулканические породы Красноярского рудного поля: 1 - гранодиорит-порфир; 2, 3 плагиогранит-порфиры, 4-9- плагиолейкогранит-порфиры.

Note. LOI - loss on ignition. $N$ - elements normalized after [3]. $E u^{*}=\left(S m_{\mathrm{N}}+G d_{\mathrm{N}}\right) / 2$. Subvolcanic rocks of Krasnoyarsk ore field: 1 granodiorite-porphyre; 2, 3- plagiogranite-porphyre; 4-9-plagiogranite-porphyres.

Таблииа 2. Отношения элелентов и ТЭФ РЗЭ в породах Красноярских штоков

Table 2. Ratio of elements and tetrad effect of REE fractionation (TEF REE) in rocks of Krasnoyarskii stocks

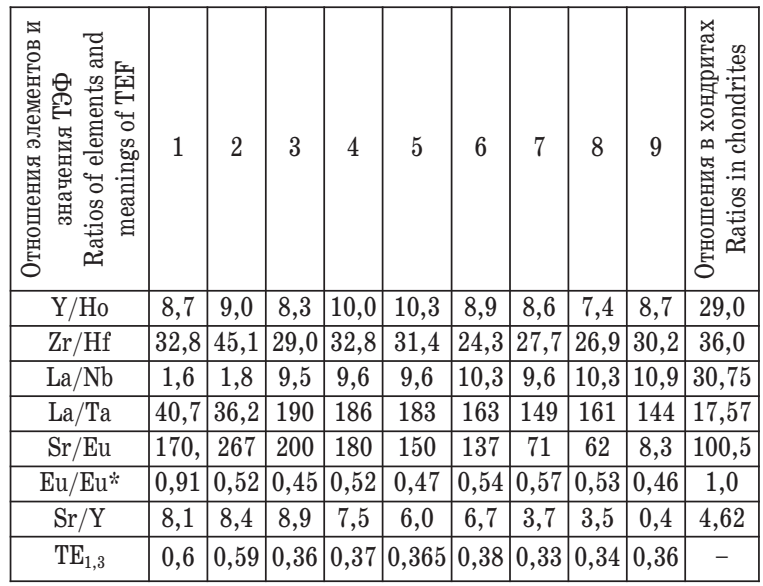

Примечание. ТЕ $E_{1.3}$ - тетрадный эффект фракиионирования РЗЭ (среднее между первой и третьей тетрадами) по В. Ирбер [6]; $E u^{*}=\left(S m_{\mathrm{N}}+G d_{\mathrm{N}}\right) / 2$. Значения в хондритах приняты по [3]. Субвулканические породы Красноярского рудного поля: 1 - гранодиорит-порфир; 2, 3- плагиогранит-порфиры, 4-9 - плагиолейкогранит-порфиры.

Note. $T E_{1,3}$ - tetrad effect of REE fractionation (average between the first and the third tetrads) after V.Irber [6 ]; Eu* $=\left(\mathrm{Sm}_{\mathrm{N}}+G d_{\mathrm{N}}\right) / 2 . \mathrm{Va}$ lues in chondrites are taken after [3]. Subvolcanic rocks of Krasnoyarsk ore field: 1 - granodiorite-porphyre; 2,3 - plagiogranite-porphyre; 4-9-plagiogranite-porphyres.

В субвулканических породах штоков проявлен тетрадный эффект фракционирования редкоземельных элементов W-типа, варьирующий от 0,33 до 0,6 (граничное значение менее 0,9 ) (табл. 2). В табл. 2 приведены также характерные 
a

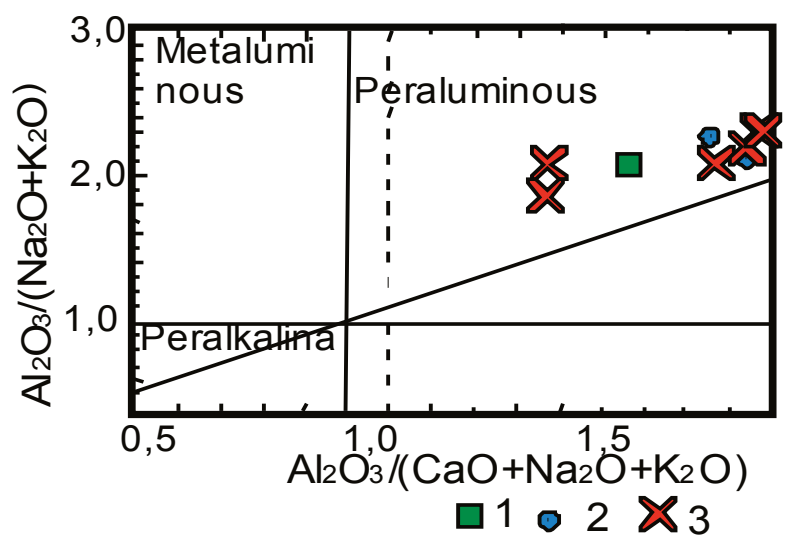

б

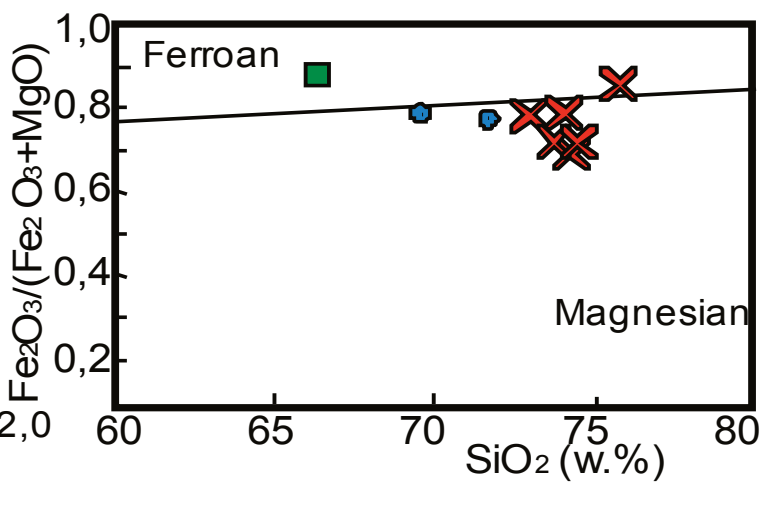

Pис. 2. Классификационные диаграмлы: а) диаграмла $\mathrm{Al}_{2} \mathrm{O}_{3} /\left(\mathrm{Na}_{2} \mathrm{O}+\mathrm{K}_{2} \mathrm{O}\right)-\mathrm{Al}_{2} \mathrm{O}_{3} /\left(\mathrm{CaO}_{\mathrm{O}}+\mathrm{Na}_{2} \mathrm{O}+\mathrm{K}_{2} \mathrm{O}\right)$ по [4]; б) диагралла $\mathrm{Fe}_{2} \mathrm{O}_{3} /\left(\mathrm{Fe}_{2} \mathrm{O}_{3}+\mathrm{MgO}\right)-\mathrm{SiO}_{2}$ по [5] для субвулканических пород коргонского комплекса Красноярского рудного поля: 1 - гранодиорит-порфиры, 2 - плагиогранит-порфиры, 3 - плагиолейкогранит-порфиры

Fig. 2. Classification plots: a) plot $\mathrm{Al}_{2} \mathrm{O}_{3} /\left(\mathrm{Na}_{2} \mathrm{O}+\mathrm{K}_{2} \mathrm{O}\right)$ vs. $\mathrm{Al}_{2} \mathrm{O}_{3} /\left(\mathrm{CaO}+\mathrm{Na}_{2} \mathrm{O}+\mathrm{K}_{2} \mathrm{O}\right)$ after [4]; б) plot $\mathrm{Fe}_{2} \mathrm{O}_{3} /\left(\mathrm{Fe}_{2} \mathrm{O}_{3}+\mathrm{MgO}\right)$ vs. $\mathrm{SiO}_{2}$ after [5] for subvolcanic rocks of Korgon complex of Krasnoyarsk ore field: 1 - granodiorite-porphyre; 2, - plagiogranite-porphyre; 3 - plagioleucogranite-porphyres

отношения элементов и сравнение с таковыми в хондритах. Следует отметить, что некоторые отношения элементов в породах устойчиво ниже хондритовых (Y/Ho, $\mathrm{La} / \mathrm{Nb}, \mathrm{Eu} / \mathrm{Eu}$ *), а другие дают разброс значений и выше, и ниже хондритовых (La/Ta, Zr/Hf, Sr/Eu, Sr/Y). Это свидетельствует о резком изменении содержаний элементов в породах, вызванных различными причинами (мантийными и коровыми процессами, мантийно-коровым взаимодействием).

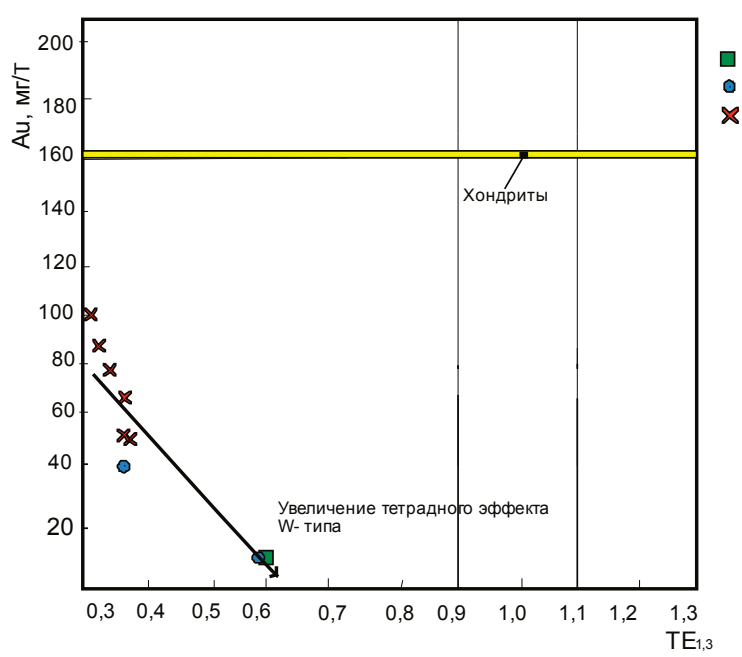

Pис. 3. Диаграмла $A u-T E_{1,3}$ по [7] для пород субвулканического комплекса Красноярского рудного поля. Желтое поле показывает концентрации золота в магматических породах по [8]; содержания золота в хондритах по [9]. Условные обозначения - на рис. 2

Fig. 3. Plot Au vs. TE $E_{1,3}$ after [7] for rocks of subvolcanic complex of Krasnoyarsk ore field. Yellow field shows gold concentration in magmatic rocks after [8]; gold content in chondrites is af ter [9]. Legend is in the Fig. 2
На диаграмме соотношений $\mathrm{Au}-\mathrm{TE}_{1,3}$ в породах субвулканического комплекса наблюдается увеличение ТЭФ РЗЭ W-типа с уменьшением концентраций золота (рис. 3). Содержания золота повсеместно ниже хондритовых значений. Следовательно, золото как мантийный элемент в процессе генерации риолитов и субвулканических образований претерпело значительные трансформации в сторону значительных снижений концентраций металла в породах.

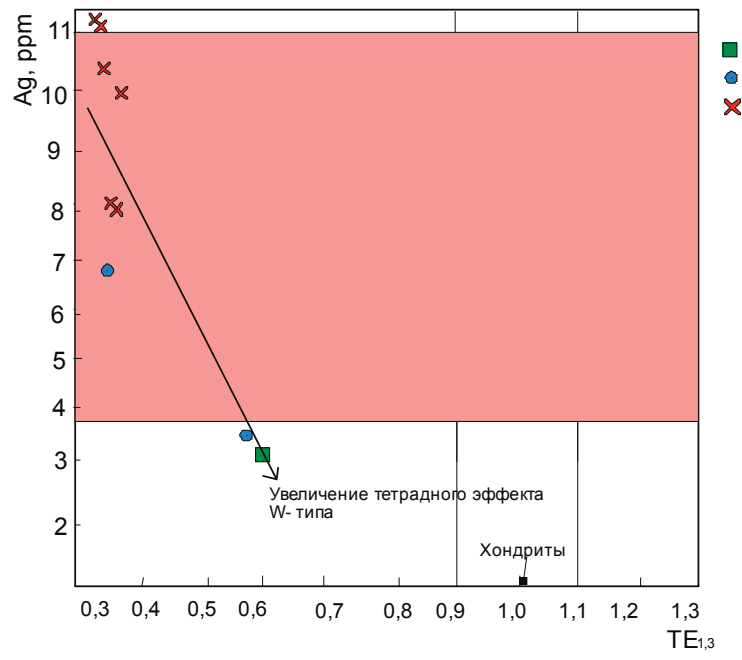

Puc.4. Диаграмла Ag-TE 1,3 для пород субвулканического комплекса Краснолрского рудного поля. Розовое поле показывает вариации кониентраций серебра в магматических породах по [8]; содержания серебра в хондритах по [9]. Условные обозначения-на рис. 2

Fig. 4. Plot Ag vs. TE ${ }_{1,3}$ for rocks of subvolcanic complex of Krasnoyarsk ore field. The pink field shows silver concentration in magmatic rocks after [8]; silver content in chondrites is after [9]. Legend is in the Fig. 2 
Совершенно иная картина на такой же диаграмме наблюдается для серебра. Концентрации его в субвулканических породах выше, чем в хондритах, и тренд увеличения величин ТЭФ РЗЭ значительно круче, чем для золота, хотя тенденция снижения концентраций серебра с увеличением значений ТЭФ РЗЭ сохраняется (рис. 4).

\section{Оруденение Красноярского рудного поля}

Оруденение контролируется зоной смятия и дробления риолитовых порфиров коргонской свиты широтной и субширотной ориентировок. В отдельных тектонических швах зоны смятия выявляется сбросо-сдвиговая кинематика. Она контролирует размещение субвулканических тел, кварцевых жил и метасоматитов Красноярского месторождения и ряда проявлений $\mathrm{Cu}, \mathrm{Zn}, \mathrm{Co}, \mathrm{As}, \mathrm{W}$. Простирание жил СЗ3 (азимуты 280-290), падение на ЮЮЗ под углами 55-70 . Красноярское месторождение представляет собой своеобразный линейный штокверк из сближенных кварцевых жил и мелких прожилков между ними. Известно семь наиболее крупных жил, из которых наибольший интерес представляет жила № 1 (главная).

Жила № 1 имеет азимут падения $200^{\circ}$ под углом $60^{\circ}$; прослежена по простиранию канавами с поверхности на 1000 м и разведана на глубину до 100 м двумя штольнями длиной 75 и 200 м. Мощность жилы меняется от первых сантиметров до 3,6 м. Сопровождается аргиллизитами в виде окремнения с иллитом, монтмориллонитом и каолинитом в виде гнёзд. Местами кварц ноздреватый. Главные гипогенные минералы (галенит, халькопирит, блёклые руды, энаргит, сфалерит) и гипергенные (церуссит, малахит, азурит, редко ковеллин) развиты как в кварце жил, так и в их зальбандах. Их количество и соотношение меняется в широких пределах - от редкой рассеянной вкрапленности до массивных руд. Выделяются восточная (богатая) и западная (бедная) части жилы № 1. В восточной части наблюдаются наиболее богатые сливные руды, где помимо преобладающего галенита присутствуют теннантит, тетраэдрит, энаргит. В рудах установлены содержания (\%): $\mathrm{Pb}$ - от 0,5 до 60,$2 ; \mathrm{Sb}$ - от 1,5 до $10 ; \mathrm{Cu}$ - от 0,8 до 8,8; $\mathrm{Zn}$ - от 0,04 до 0,17; $\mathrm{Ag}$ и $\mathrm{Au}$ (по штольне № 1) - до 5000 и 29,6 г/т, соответственно (по канавам до 3497 и 27,2 г/т, соответственно). Кроме этого, в повышенных содержаниях в рудах присутствуют $\mathrm{Mo}, \mathrm{Cd}$ и As. Редко отмечаются повышенные концентрации ртути и висмута. В западном направлении жила выклинивается, в восточном направлении её следует прослеживать. Подсчёт запасов свинца категорий $\mathrm{B}+\mathrm{C}_{1}$ до глубины 130 м даёт цифру 1725 т. Средняя мощность рудного тела по месторождению составляет около 1 м $(99 \mathrm{~cm})$, среднее содержание свинца - 3,4 \% . Баранчинским рудоуправлением запасы $\mathrm{Au}$ категорий $\mathrm{B}+\mathrm{C}_{1}+\mathrm{C}_{2}$ оценены в 63,2 кг (по категории $\mathrm{C}_{1}$ они составляли 140,2 кг) при среднем содержании 2,72 г/т и средней мощности тела 87 см. По состоянию на
01.01.1956 г. запасы отнесены к забалансовым в количестве 280,4 кг $\left(\mathrm{C}_{1}=140,2 \kappa \Gamma+\mathrm{C}_{2}=140,2\right.$ кг). На остальные металлы подсчёт запасов не проводился.

Жила № 2 расположена в 4 м к северу от жилы № 1. Она представлена серией прожилков мощностью 2-3 см из кварца, хлорита, иллита, монтмориллонита и кальцита с примазками малахита, и азурита с азимутом падения 180-200', углами падения 70-80'. Общая мощность жильной зоны варьирует от 1 до 3 м. Содержания $\mathrm{Au}-$ 0,2-0,4 г/т, Ag - 8,9-20,8 г/т, Pb - 0,2-0,45\%, $\mathrm{Sb}-0,03-0,07 \%$. Жильная зона сопровождается аргиллизитами.

Жила № 3 расположена в 3 м севернее жилы № 2. Она преимущественно кварцевая с примесью кальцита, хлорита, сидерита мощностью 1-4 м с азимутом падения $205^{\circ}$, углом падения $80^{\circ}$. Содержание $\mathrm{Au}$ от 0,5 до 11,6 г/т, $\mathrm{Ag}$ - от 12 до 491,8 г/т, $\mathrm{Pb}$ - от 1,6 до 9,54 \%, Sb - от 0,3 до $1,17 \%$. Кедровской партией вскрыта в 10 м восточнее при мощности 15 см с незначительным содержанием сульфидов $\mathrm{Pb}, \mathrm{Cu}$.

Жилы № 4, 5 расположены соответственно в 30 м севернее и в 65 м южнее жилы № 1 (р-н канавы № 1) в коренном залегании в обнажениях. Канавами не вскрывались, не прослеживались и не опробовались как безрудные (Котляров). Жилой № 5 могут являться прожилки безрудного кварца мощностью до 10-15 см, пересечённые К-1000 в её начале в 45 м южнее жилы № 1.

Жuла № 6 кварц-сидеритового состава с хлоритом, иллитом, монтмориллонитом и вкрапленностью пирита расположена в 220 м южнее жилы № 1 по левому борту ключа Аммональный. Мощность её 40 см, азимут падения $160^{\circ}$, углы падения 65-70 . Прослежена в ЮЗ направлении на 90 м. По химическим анализам значимые содержания $\mathrm{Pb}, \mathrm{Cu}, \mathrm{Au}$ и $\mathrm{Ag}$ отсутствуют (в лучшем случае «следы»).

Жила № 7 расположена в 190 м ниже (южнее) по склону от жилы № 1 на водоразделе ручьёв Аммональный и Зайков. Залегание её субгоризонтальное (падение под углами $5-10^{\circ}$ на ЮЮЗ). Мощность 10-20 cм, прослежена по простиранию на 11,2 м, на всём протяжении содержит крупнокристаллический галенит, теннантит, тетраэдрит, редко энаргит, а также халькопирит, пирит, малахит и азурит, образующие гнезда размером до 10-20 см и более, вплоть до сливных массивных руд, аналогичных наблюдаемым в восточной части жилы № 1. Мощные аргиллизиты развиты в висячем боку жилы. Содержания золота составляют от 0,5 до 8,9 г/т, серебра - от 15 до 127 г/т. В канавах установлено, что жила взброшена (северный край опущен по отношению к южному примерно на $1 \mathrm{m)} \mathrm{разломом} \mathrm{субширотного} \mathrm{простирания} \mathrm{кру-}$ того южного падения. В 15 м северо-западнее канавой вскрыта также субгоризонтальная жила мощностью 10 см с гнездами галенита. Задирковая проба показала содержания $\mathrm{Pb}-15,1 \%, \mathrm{Cu}-$ 
$2,35 \%, \mathrm{Zn}-0,1 \%$. Жила подсечена двумя канавами и прослежена по простиранию в свалах от правого борта ручья Аммональный до русла ручья Зайков. Магистральной канавой К-1000 длиной $141 \mathrm{~m}$ на водоразделе ручьёв Аммональный-Зайков жила № 1 пересечена под острым углом в интервале ПК56-59 при истинной мощности около $1 \mathrm{~m}$, где она представлена зоной 0,6-0,7 м сливных полиметаллических руд, в лежачем боку зона ожелезнённой кварцевой сыпучки сильно ноздреватого кварца, глинистых минералов иллит-монтмориллонитового ряда также отвечает околорудным аргиллизитам. По жиле отобрано три бороздовые пробы, показавшие содержания: $\mathrm{Ag}$ - 2268-6673 г/т, $\mathrm{Au}$ $26-43,8$ г т, $\mathrm{Pb}-$ до $15,9 \%, \mathrm{Cu}-$ до $7,25 \%, \mathrm{Zn}-$ $0,2 \%, \mathrm{As}, \mathrm{Sb}->1 \%, \mathrm{Bi}-0,06 \%, \mathrm{Cd}-0,03$.

В 400 м западнее и в 250 м гипсометрически ниже жила № 1 подсечена канавой К-1003 в правом борту ручья Аммональный. Здесь её мощность составляет 3 м. В ноздреватом кварце вкрапленность пирита, галенита и блёклых руд рассеянная не более 1-3\%, максимальные содержания $\mathrm{Ag}$ 123 г/т, Au - 3,04 г/т. Далее в западном направлении жила прослежена в отвалах старых канав и в виде обломков на склоне с содержаниями $\mathrm{Au}$ от 0,92 до 6,5 г/т, $\mathrm{Ag}$ от 2,5 до 126 г/т. В восточном напра- влении от канавы K-1000 жила также прослеживается вначале по канавам, затем по обломкам в делювии с убыванием степени минерализации и, соответственно, содержаний золота от 0,28 до 7,86 г/т, серебра от 25 до 235 г/т, что связано с увеличением уровня эрозионного среза жилы.

На площади рудного поля кроме коренного оруденения известно пять россыпей золота, частично отработанных до 1950 г.: Красноярская, Кумирская, Щебнюхинская, Кытминская, Татарская.

\section{Минеральный состав руд}

\section{Красноярского месторождения}

По текстурным взаимоотношениям (пересечениям прожилков и дроблению) в составе эндогенных руд выделяются три стадии минерализации. Первые две стадии можно рассматривать рудными, а третью стадию - пострудной. Типоморфной ассоциацией руд месторождения является теннантит-тетраэдрит-энаргит-люцонитовая, указывающая на значительную сернистость сульфидов, что характерно для высокосерных эпитермальных систем $[10,11]$. Минеральный состав и последовательность минералообразования в рудах при визуальном изучении, а также исследованиях в шлифах и аншлифах представлены в табл. 3

Таблица 3. Парагенетическая схема последовательности минералообразования

Table 3. $\quad$ Paragenetic scheme of mineral forming sequence

\begin{tabular}{|c|c|c|c|c|}
\hline \multirow{2}{*}{$\begin{array}{l}\text { Минералы/ } \\
\text { Minerals }\end{array}$} & \multicolumn{3}{|c|}{ Эндогенные стадии/Endogenetic stages } & \multirow{2}{*}{$\begin{array}{l}\text { Гипергенез / } \\
\text { Gipergenesis }\end{array}$} \\
\hline & $\begin{array}{l}1 \text { стадия/ } \\
1 \text { stage }\end{array}$ & $\begin{array}{l}2 \text { стадия/ } \\
2 \text { stage }\end{array}$ & $\begin{array}{l}3 \text { стадия/ } \\
3 \text { stage }\end{array}$ & \\
\hline Кварц/Quartz & $\longrightarrow$ & 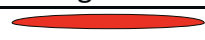 & 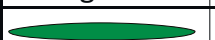 & \\
\hline Кальцит/Calcite & $\longrightarrow$ & $\longrightarrow$ & 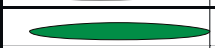 & \\
\hline Сидерит/Siderite & $\longrightarrow$ & $\longrightarrow$ & $\infty$ & \\
\hline Пирит/Pyrite & $\longrightarrow$ & 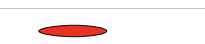 & & \\
\hline Галенит/Gal enite & $\longrightarrow$ & $\lessdot$ & & \\
\hline Сфалерит/Sphale rite & & 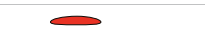 & & \\
\hline Халькопир ит/Chalcopyrite & - & - & & \\
\hline Теннантит/Tenna ntite & & 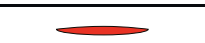 & & \\
\hline Тетраэдрит/Tetrahedrite & & $\longrightarrow$ & & \\
\hline Энаргит/Enargite & & 2 & & \\
\hline Люцонит/Luzonite & & - & & \\
\hline Электрум/Electrum & - & $\Longleftarrow$ & & \\
\hline Аргентит/Argentite & $\longrightarrow$ & 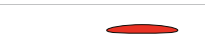 & & \\
\hline Гессит/Hessite & 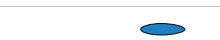 & 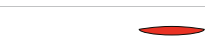 & & \\
\hline Тетрадимит/Tetrademite & 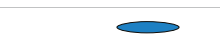 & 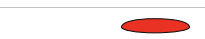 & & \\
\hline Алтаит/Altaite & - & - & & \\
\hline Иллит/Illite & $\longrightarrow$ & 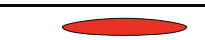 & & \\
\hline Монтмориллонит/Montmorillonite & 2 & 2 & & \\
\hline Каолинит/Kaolinite & $\longrightarrow$ & $\longrightarrow$ & & \\
\hline Хлорит/Chlorite & $\longrightarrow$ & 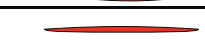 & & \\
\hline Церуссит/Cerussite & & & & 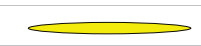 \\
\hline Гематит/Hematite & & & & 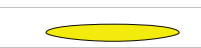 \\
\hline Малахит/Malachite & & & & 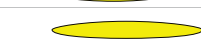 \\
\hline Азурит/Azurite & & & & $\infty$ \\
\hline Ковеллин/Covellite & & & & 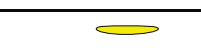 \\
\hline Ярозит/Ja rozite & & & & 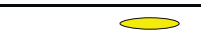 \\
\hline
\end{tabular}


Электрум тесно ассоциирует с теллуридами и имеет пробность 617-624\%。. В качестве примесей, кроме серебра, присутствуют медь и мышьяк. Размеры выделений электрума варьируют от 0,005 до 1,6 мм.

По отношениям $\mathrm{Ag} / \mathrm{Au}$ руды Красноярского месторождения следует относить к $\mathrm{Ag}$ - $\mathrm{Au}$ объектам [12], так как в них это отношение превышает 10 и достигает $135-150$.

\section{Физико-химические особенности рудного процесса}

Температуры гомогенизации первичных газово-жидких включений в кварце 1,2 и 3 генераций снижались от 255 к $245{ }^{\circ} \mathrm{C}$ и $180{ }^{\circ} \mathrm{C}$, соответственно. Солёность растворов также снижалась от 6-7 вес. \% $\mathrm{NaCl}$ до 0,5-1 вес. \% NaCl. Это свидетельствует о процессах смешения ювенильных растворов на поздних этапах становления гидротермальной системы. Некоторые термобарометрические и изотопные данные приведены в табл. 4.

таблица 4. Терлобарогеохимические и изотопные данные иссле дований минералов Красноярского месторождения

Table 4. Thermobarogeochemical and isotopic data of Krasnoyarsk deposit minerals research

\begin{tabular}{|c|c|c|c|c|c|}
\hline $\begin{array}{c}\text { Минерал } \\
\text { Mineral }\end{array}$ & $n$ & $\mid \begin{array}{c}T_{\text {roo }} / T_{\text {hom }}, \\
{ }^{\circ} \mathrm{C}\end{array}$ & $\begin{array}{c}\text { Солёность, } \\
\text { мac. } \% \text {-экв. } \mathrm{NaCl} \\
\text { Salinity, } \\
\text { eq. wt. } \% \mathrm{NaCl}\end{array}$ & $\delta^{34} \mathrm{~S}, \% 0$ & $\begin{array}{l}\delta^{18} 0, \% 0 \\
\text { SMOW }\end{array}$ \\
\hline \begin{tabular}{|l|} 
Кварц 1 \\
Quartz 1 \\
\end{tabular} & \multirow{5}{*}{2} & $265-250$ & $6,0-7,0$ & - & $15,8-16,2$ \\
\hline \begin{tabular}{|l|} 
Кварц 2 \\
Quartz 2
\end{tabular} & & $250-245$ & $2,0-1,8$ & - & $17,0-18,8$ \\
\hline \begin{tabular}{|l|} 
Кварц 3 \\
Quartz 3
\end{tabular} & & $175-185$ & $0,5-1,0$ & - & - \\
\hline \begin{tabular}{|c|} 
Пирит 1 \\
Pyrite 1 \\
\end{tabular} & & - & - & $(-3,5)-(-1,7)$ & - \\
\hline \begin{tabular}{|l|} 
Пирит 2 \\
Pyrite 2 \\
\end{tabular} & & - & - & $(-1,5)-(+5,5)$ & - \\
\hline
\end{tabular}

Примечание. $n$ - число проб; SMOW - среднее содержание в морской воде.

Note. $n$ is the number of samples; SMOW (Standard Mean Ocean Water) is the average content in sea water.

Существенно сфалерит-теннантит-галенитовые руды с хлоритом восточной части зоны № 1 формировались из хлоридно-натриевых слабо концентрированных $(7,0-6,0$ мас. \% экв. $\mathrm{NaCl})$ растворов при температуре $260-255{ }^{\circ} \mathrm{C}$. Согласно хлоритовому термометру в полиметаллических рудах хлорит формировался при температурах $255-250{ }^{\circ} \mathrm{C}$. $\mathrm{Co}^{-}$ держания тяжёлого изотопа серы в пирите отвечает магматогенному источнику, а кислорода - метеорным водам.

Для оценки зависимостей температур и фугитивности серы $\left(f \mathrm{~S}_{2}\right)$ при кристаллизации руд Красноярского месторождения были использованы фазовые взаимоотношения и изменения состава минералов в системе Fe-Zn-S [13]. Предварительно в составе сфалерита 1 генерации содержание $\mathrm{FeS}$ определено в количестве $0,5-8,4$ мол. \%, а в составе сфалерита 2 генерации - 1-5,7 мол. \%. На основании этих данных изменение фугитивности серы можно отразить на диаграмме (рис. 5). С понижением температуры кристаллизации минеральных парагенезисов происходило снижение фугитивности серы. Для первой стадии фугитивность серы составляет $(-10-11)$, а для второй стадии $(-15-16)$.

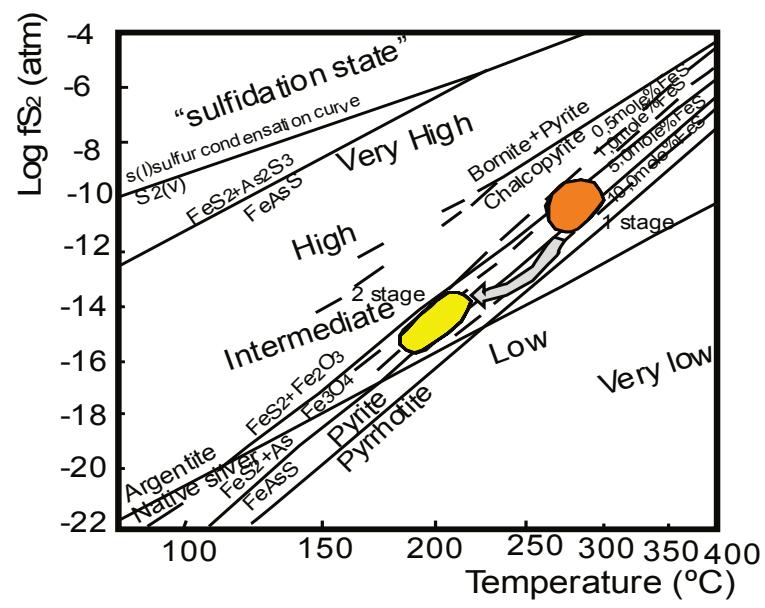

Puc.5. Диагралма Logf $S_{2}$ - температура для рудной минерализации Красноярского месторождения. Изоплеты FeS coдержаний для сфалерита рассчитаны с использованием уравнений по [13]. Оранжевое поле - приблизительные оценки фугитивности серы и температурные условия для 1 стадии, жёлтое поле - для 2 стадии

Fig. 5. Plot Logf $S_{2}$ vs. temperature for ore mineralization for Krasnoyarsk deposit. Isopleths of FeS content for sphalerite are calculated using the equations after [13]. Orange field is the approximate estimates of sulfur fugacity and temperature for $1^{\text {st }}$ stage, yellow field - for $2^{d}$ stage

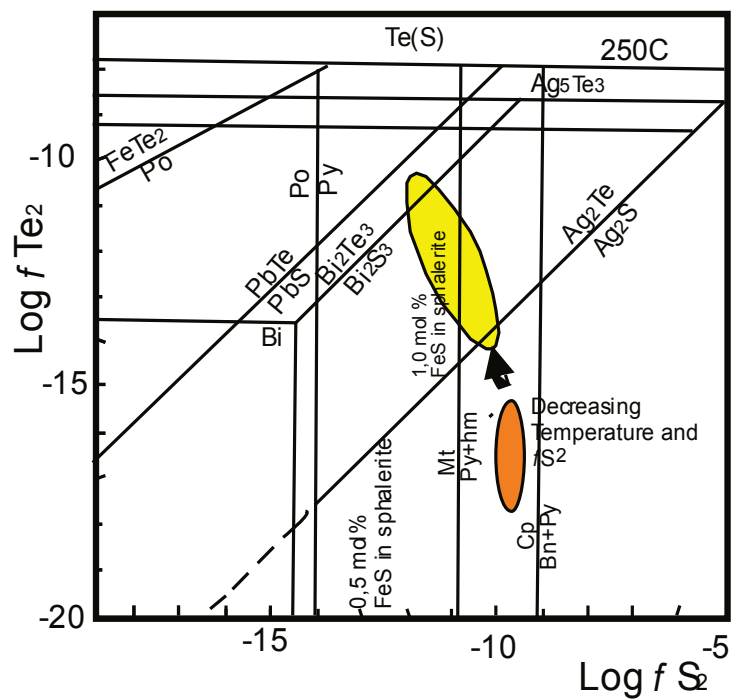

Puc. 6. Диаграмла LogfTe 2 - Logf $S_{2}$ для руд Красноярского месторождения. Диаграмла показывает равновесие между теллуридами и сульфидами для руд Красноярского месторождения при $250{ }^{\circ} \mathrm{C}$ в условиях газового насыщения по [14]. Оранжевое поле - для сульфидной ассоциации, жёлтое поле - для теллуридной ассоциации руд Красноярского месторождения

Fig. 6. Plot LogfTe $e_{2}$ vs. Logf $S_{2}$ for ores of Krasnoyarsk deposit. The plot shows the equilibria between tellurides and sulfides for ores of Krasnoyarsk deposit at $250{ }^{\circ} \mathrm{C}$ in condition of vapor saturation after [14]. Orange field is for sulfide association, yellow - for telluride association of Krasnoyarsk deposit ores 
Условия отложения минералов теллуридного парагенезиса могут быть также определены с использованием равновесий между сульфидами и теллуридами. Вариации фугитивностей $\mathrm{Te}_{2}$ и $\mathrm{S}_{2}$ в условиях равновесия теллуриды-сульфиды при $250{ }^{\circ} \mathrm{C}$ по [14] показаны на рис. 6.

Сульфидная ассоциация минералов была отложена при температуре $250{ }^{\circ} \mathrm{C}$ при фугитивности $f \mathrm{~S}_{2}$ от $-10,5$ до $-9,5$ и фугитивности $f \mathrm{Te}_{2}$ менее -15 . Теллуридный парагенезис отлагался при значениях $\log f \mathrm{~S}_{2}$ в диапазоне от -12 до -10 и фугитивности $f \mathrm{Te}_{2}$ от -14 до -10 .

Оценка фугитивности кислорода и $\mathrm{pH}$ среды может быть проведена в комбинации с фазовыми взаимоотношениями в системе Fe-O-S. Учитывая определённые молекулярные количества $\mathrm{FeS}$ в сфалерите и ассоциации глинистых минералов - иллита и каолинита, построена диаграмма $\mathrm{Log} f \mathrm{O}_{2}-\mathrm{pH}$ (рис. 7). Фугитивность кислорода оценена в пределах от $-39,5$ до -37 . При этом она увеличивалась при отложении энаргита, теннантита и теллуридов. рН варьировала от 4 до 5,4.

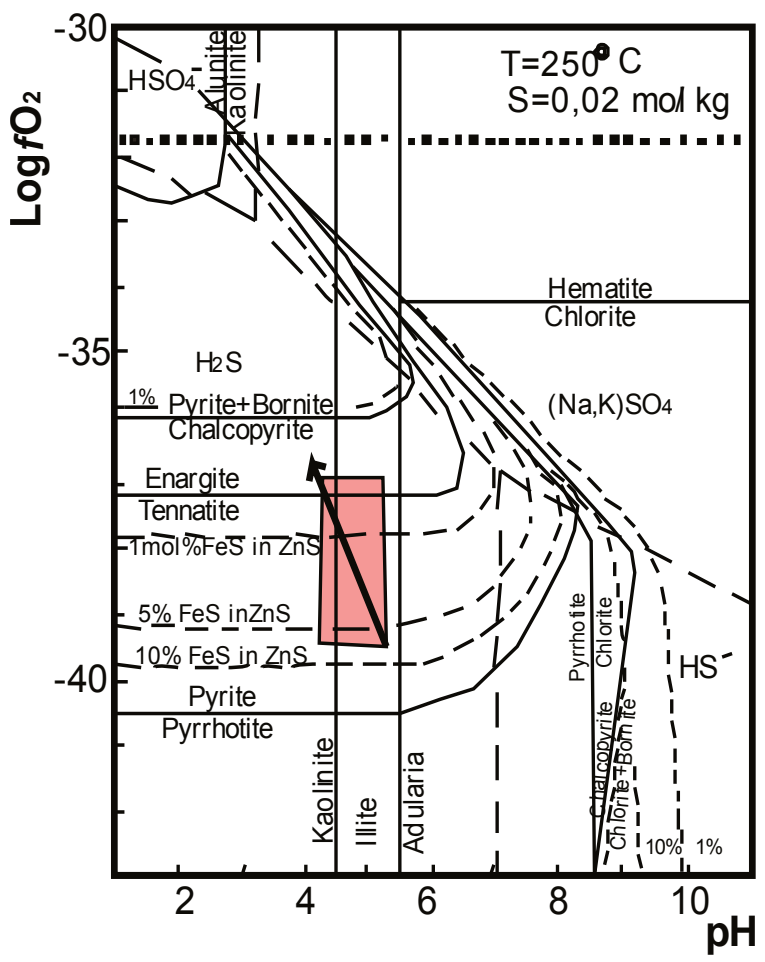

Puс. 7. Диагралла $\mathrm{LogfO}_{2}-$ рН для руд Красноярского месторож дения. Значения $\mathrm{pH}$ и $\mathrm{fO}_{2}$ первичных рудных флюидов мо дифицированы по [15]. Стрелкой показано изменение со стояния рудных флюидов от нейтральных $к$ слабо ки слотныл. Розовыл иветол показано поле стабильности для различных минералов с мол. \% FeS в сралерите при $T=250^{\circ} \mathrm{C}, \Sigma S=0,02$ мол $/ \kappa 2$

Fig. 7. Plot LogfO $\mathrm{O}_{2}$ vs. $\mathrm{pH}$ for ores of Krasnoyarsk deposit. Values of $\mathrm{pH}$ and $\mathrm{fO}_{2}$ of primary ore fluids modified after [15]. Arrow shows the ore fluid state changing from neutral to slightly acidic. Pink colour shows stability field for different minerals with mol. $\%$ FeS in sphalerite at $T=250^{\circ} \mathrm{C}, \Sigma S=0,02 \mathrm{~mol} / \mathrm{kg}$

\section{Интерпретация результатов}

В настоящее время предполагается три главных процесса, приводящих к образованию и дифференциации риолитового материала в вулканогенных поясах с эпитермальным оруденением: кристаллизационное фракционирование [16, 17], частичное плавление континентальной коры $[18,19]$ и термогравитационная диффузия, при которой химическое фракционирование достигалось при полном расплавлении [20].

Популярная модель термодиффузии в жидкой среде, предложенная В. Хилдретом [20], способна объяснить различие интерпретаций образования риолитов, в том числе и субвулканических кислых образований, в различных районах. Она раскрывает механизм обогащения совместимыми сидерофильными элементами (такими как Y, Sc и $\mathrm{Mn}$ ) и несовместимыми элементами, характерной особенностью которых является несовместимость с любой системой и прежде всего с системой кристалл-жидкость. По указанным параметрам к Красноярской магмо-рудно-метасоматической системе может быть применима именно модель термодиффузии. Она также даёт объяснение механизмам фракционирования тяжёлых редкоземельных элементов относительно лёгких без привлечения фракционирования циркона или апатита. Модель помогает понять процесс обогащения флюидной фазы магматитов благородными элементами. Главные летучие компоненты в большинстве магм представлены $\mathrm{H}_{2} \mathrm{O}, \mathrm{CO}_{2}$ и $\mathrm{S}_{2}$ или $\mathrm{H}_{2} \mathrm{~S}$ [21]. В субвулканических породах проявлен тетрадный эффект фракционирования РЗЭ W-типа и его величины негативно коррелируются с содержаниями золота и серебра в породах.

Однако модель термодиффузии для условий Красноярской магмо-рудно-метасоматической системы была генерирована в результате процессов смешения базальтового источника и корового материала, что подтверждается анализом соотношений $\mathrm{La} / \mathrm{Nb}$ и $\mathrm{Ce} / \mathrm{Y}$ (рис. 8).

Известно, что высоко-серные эпитермальные золото-серебряные месторождения характеризуются наличием в рудах энаргита и люцонита $[21,23,24]$, как это имеет место и в рудах Красноярского месторождения. Установлено, что высокосерные эпитермальные $\mathrm{Au}-\mathrm{Cu}$ месторождения развиваются в обстановках, где летучие компоненты поднимаются вверх очень быстро из глубинного магматического источника и не взаимодействуют с вмещающими породами и окружающими водами на глубине, становясь очень горячими кислыми гидротермальными флюидами, которые только на эпитермальных близ-поверхностных уровнях взаимодействуют с вмещающими породами [25]. Прогрессивное охлаждение и нейтрализация горячих кислых гидротермальных флюидов вмещающими породами в близ-поверхностной обстановке продуцирует килотно-сульфатный тип изменений и зо- 
нальные аргиллизиты с формированием типичных ассоциаций пирита, энаргита, люцонита [26].

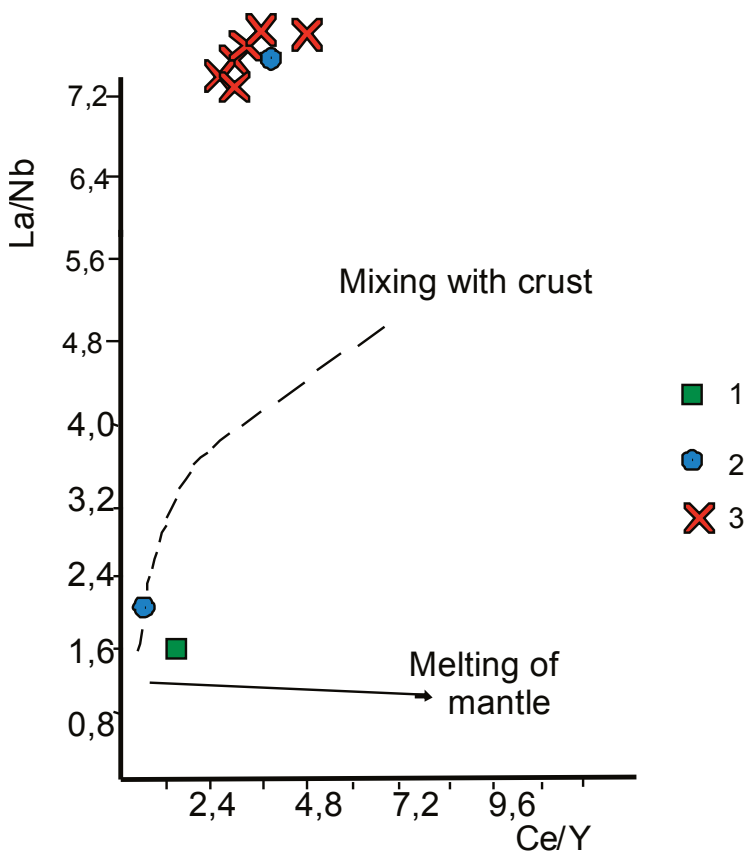

Puс. 8. Диаграмлма соотношений La/Nb-Ce/Y no [22] для субвулканических пород Красноярского рудного поля. Условные обозначения - на рис. 2

Fig. 8. Plot ratio La/Nb vs. Ce/Y after [22] for subvolcanic rocks of Krasnoyarsk ore field. Legend is in the Fig. 2

Аналогичный механизм предполагается и для формирования руд Красноярского месторождения. Физико-химические и термодинамические условия формирования руд месторождения весьма показательны и находят много общих черт с объектами подобного типа, описанными в различных регионах $[27,28]$. От сульфидной стадии к теллуридной в рудах Красноярского месторождения происходило понижение температуры кристаллизации при значительном снижении фугитивности серы и повышении фугитивности теллура и кислорода. От ранней стадии к поздней происходила трансформация $\mathrm{pH}$ среды от близ-нейтральной в сульфидном парагенезисе до сильно кислой среды при отложении теллуридов. Такая смена термодинамического режима генерации руд объясняется повышением уровня становления магматического глубинного очага [29, 30].

В последнее время стало известно, что месторождения порфирово-эпитермальных минеральных систем ассоциированы с островодужным магматизмом в пределах конвергентных геодинамических обстановок. Такие системы зональны и глубже эпитермального оруденения должно локализоваться порфировое и, возможно, скарновое. Совмещение порфирового и эпитермального $\mathrm{Au}-\mathrm{Ag}$ оруденения отмечается в рудах Михеевского место- рождения на Урале [28], $\mathrm{Au}-\mathrm{Ag}$ месторождениях Роговик и Баимка на Северо-Востоке России $[31,32]$, в Айлаошаньском рудном поясе на Северо-Западе Китая [33].

В Красноярском рудном поле возможно выявление, кроме эпитермального, медно-порфирового и скарнового оруденения.

\section{Заключение}

Магмо-рудно-метасоматическая система Красноярского рудного поля охватывает вулканиты риолитового состава, субвулканические штоки плагиолейкогранит-порфиров и плагиогранитпорфиров коргонского комплекса среднего девона. Субвулканические образования формировались в результате смешения мантийного и корового материала, что сказалось на формировании околорудных метасоматитов и эпитермального оруденения. В объяснении формирования геохимического облика магматитов, метасоматитов и рудных парагенезисов привлекается модель термодиффузии в жидкой среде. Основную роль среди летучих компонентов играли $\mathrm{H}_{2} \mathrm{O}, \mathrm{CO}_{2}$ и $\mathrm{S}_{2}$ или $\mathrm{H}_{2} \mathrm{~S}$. Поэтому в породах проявлен ТЭФ РЗЭ W-типа. С уменьшением величин ТЭФ РЗЭ увеличиваются концентрации $\mathrm{Au}$ и $\mathrm{Ag}$ в субвулканических образованиях. Околорудные метасоматиты охватывают комплекс окварцевания, аргиллизации с развитием каолинита, монтмориллонита и иллита.

Эпитермальное оруденение Красноярского рудного поля отнесено к высоко-серному типу с парагенезисами блёклых руд, энаргита и люцонита, типоморфных высоко-серных сульфидов. Вторая рудная стадия характеризовалась проявлением теллуридов (тетрадимита, алтаита, гессита и других). Такая резкая смена парагенезисов вызвана изменениями в глубинном очаге с повышением его уровня. Резко кислотная обстановка формирования оруденения создавала интенсивные процессы окремнения и окварцевания и изменение фугитивностей серы, теллура и кислорода с варьированием $\mathrm{pH}$ среды от почти нейтральной до сильно кислой. Сера сульфидов имела мантийные метки, а изотопы кислорода отвечают значениям метеорных вод. Флюиды, формировавшие оруденение, в процессе быстрого подъёма не смешивались с метеорными водами и лишь на близ-поверхностном уровне происходило смешение ювенильных флюидов и метеорных вод.

В районе Красноярского рудного поля может быть выявлено, помимо эпитермального, меднопорфировое и скарновое оруденение.

Работа выполнена при поддержке регионального гранта РФФИ «Петрология магматизла и генезис оруденения Коргоно-Красноярского рудного района Алтайского края» (номер проекта: 18-45-220022, код и название конкурса: p_a, региональный конкурс проектов фундаментальных научных исследований). 


\section{СПИСОК ЛИТЕРАТУРЫ}

1. White N.C., Hedenquist J.W. Epithermal environments and styles of mineralization: Variations and their causes, and guidelines for exploration // Journal of Geochemical Exploration. - 1990. V. 36. - № 1-3. - P. 445-474. URL: https://doi.org/10.1016/ 0375-6742(90)90063-G (дата обращения 23.03.2018).

2. Гусев Н.И., Шокальский С.П., Гусев А.И. Возраст магматизма (U-Pb, SHRIMP II), контролирующего эпитермальное оруденение Новофирсовского золоторудного узла (Алтай) // Региональная геология и металлогения. - 2011. - № 45. - С. 98-105.

3. Anders E., Grevesse N. Abundances of the elements: meteoritic and solar / Geochimica et Cosmochimica Acta. - 1989. - V. 53. № 1. - P. 197-214. DOI: 10.1016/0016-7037(89)90286-X.

4. Maniar P.D., Piccoli P.M. Tectonic discrimination of granitoids // Geological Society of America Bulletin. - 1989. - V. 101. № 5. - P. 635-643. DOI: 10.1130/0016-7606(1989)101<0635: TDOG $>2.3 . \mathrm{CO} ; 2$.

5. Villaseca C., Barbero L., Herreros V. A re-examination of the typology of peraluminous granite types in intracontinental orogenic belts / Transactions of the Royal Society of Edinburgh: Earth Sciences. - 1998. - V. 89. - № 2. - P. 113-119. D0I: $10.1017 / \mathrm{S} 0263593300007045$

6. Irber $\mathrm{W}$. The lanthanide tetrad effect and its correlation with $\mathrm{K} / \mathrm{Rb}$, $\mathrm{Eu} / \mathrm{Eu} * \mathrm{Sr} / \mathrm{Eu}, \mathrm{Y} / \mathrm{Ho}$, and $\mathrm{Zr} / \mathrm{Hf}$ of evolving peraluminous granite suites // Geochimica et Cosmochimica Acta. - 1999. - V. 63. № 3-4. - P. 489-508. DOI: 10.1016/S0016-7037(99)00027-7. URL: https://doi.org/10.1016/S0016-7037(99)00027-7 (дата обращения 01.04.2018).

7. Гусев А.И. К геохимии акцессорного пирита Кошрабадского массива Западного Узбекистана // Актуальные проблемы геологии, геофизики и металлогении: материалы конференции, посвященной 80-летию создания Института геологии и геофизики и 105-летию со дня рождения академика Х.М. Абдуллаева. - Ташкент, 2017. - С. 229-232.

8. Виноградов А.П. Среднее содержание химических элементов в горных породах // Геохимия. - 1962. - № 7. - С. 555-571.

9. Wasson J.T., Kallemeyn G.W., Runcorn S.K., Turner G., Woolfson M.M. Compositions of chondrites // Philosophical Transactions of the Royal Society A: Mathematical, Physical \& Engineering Sciences. - 1988. - V. 325. - № 1587. - P. 535-544. DOI: 10.1098/rsta.1988.0066. URL: https://doi.org/10.1098/ rsta.1988.0066 (дата обращения 01.04.2018).

10. Meyer C., Hemiey J.J. Wall rock alteration // Geochemistry of Hydrothermal Ore Deposits / Ed. by H.L. Barnes. - New York: Holt, Rinehart and Winston, 1967. - P. 166-235.

11. Hedenquist J.W. Precious metal vein systems in the National District, Humboldt County, Nevada; discussion // Economic Geology. - 1986. - V. 81. - № 4. - P. 1020-1023. URL: https://doi.org/ 10.2113/gsecongeo.81.4.1020 (дата обращения 23.03.2018).

12. Золоторудные месторождения нетрадиционных типов - основа укрепления сырьевой базы в районах золотодобычи Алтая / С.С. Вартанян, Ю.М. Щепотьев, А.И. Зайцев, Н.П. Бедарев, Ю.Н. Николаев // Руды и металлы. - 2006. - № 3. - С. 5-13.

13. Scott S.D., Barnes H.L. Sphalerite geothermometry and geobarometry // Economic Geology. - 1971. - V. 66. - № 4. P. 653-669. URL: https://doi.org/10.2113/gsecongeo.66.4.653 (дата обращения 23.03.2018).

14. Afifi A.M., Kelly W.C., Essene E.J. Phase relations among tellurides, sulfides, and oxides; I, Thermochemical data and calculated equilibria // Economic Geology. - 1988. - V. 83. - № 2. P. 377-394. URL: https://doi.org/10.2113/gsecongeo.83.2.377 (дата обращения 23.03.2018).

15. John D.A. Miocene and Early Pliocene epithermal gold-silver deposits in the Northern Great basin, Western United States: characteristics, distribution, and relationship to magmatism // Economic Geology. - 2001. - V. 96. - № 8. - P. 1827-1853. URL: https://doi.org/10.2113/gsecongeo.96.8.1827 (дата обращения 23.03.2018).

16. Cameron M., Bagby W.C., Cameron K.L. Petrogenesis of Voluminous mid-Tertiary ignimbrites of the Sierra Madre Occidental, Chihuahua, Mexico // Contributions to Mineralogy and Petrology. - 1980. - V. 74. - № 3. - P. 271-284. URL: https://doi.org/ 10.1007/BF00371697 (дата обращения 23.03.2018).

17. Bagby W.C., Cameron K.L. Cameron M. Contrasting evolution of calc-alkalic volcanic and plutonic rocks of western Chihuahua, Mexico // Journal of Geophysical Research. Solid Earth. - 1981. V. 86. - Iss. B11. - P. 10402-10410. URL: https:// doi.org/10.1029/JB086iB11p10402 (дата обращения 23.03.2018).

18. Moll E.J. Geochemistry and petrology of Mid-Tertiary ash flow tuffs from the Sierra el Virulento Area, eastern Chihuahua, Mexico // Journal of Geophysical Research. Solid Earth. - 1981. V. 86. - Iss. B11. - P. 10321-10334. URL: https://doi.org/ 10.1029/JB086iB11p10321 (дата обращения 23.03.2018).

19. Pleistocene high-silica rhyolites of the Coso Volcanic Field, Inyo County, California / C.R. Bacon, R. Macdonald, R.L. Smith, P.A. Baedecker // Journal of Geophysical Research. Solid Earth. 1981. - V. 86. - Iss. B11. - P. 10223-10241. URL: https:// doi.org/10.1029/JB086iB11p10223 (дата обращения 23.03.2018).

20. Hildreth W. Gradients in silicic magma chambers: Implications for lithospheric magmatism // Journal of Geophysical Research. Solid Earth. - 1981. - V. 86. - Iss. B11. - P. 10153-10192. URL: https://doi.org/10.1029/JB086iB11p10153 (дата обращения 23.03.2018).

21. Sillitoe R.H., Hedenquist J.W. Linkages between Volcanotectonic Settings, Ore-Fluid Compositions and Epithermal Pressious Metal Deposits // Society of Economic Geologists. Special Publication. - 2003. - V. 10. - P. 315-343.

22. Barbarin B. A review of the relationships between granitoid types, their origins and their geodynamic environments // Lithos. 1999. - V. 46. - Iss. 3. - P. 605-626. URL: https://doi.org/ 10.1016/S0024-4937(98)00085-1 (дата обращения 23.03.2018).

23. Cooke D.R., Simmons S.F. Characteristics and genesis of epithermal gold deposits // Reviews in Economic Geology. - 2000. V. 13. - P. 221-244.

24. Enargite-luzonite hydrothermal vents in Manus Back-Arc Basin: submarine analogues of high-sulfidation epithermal mineralization / V.M. Dekov, O. Rouxel, K. Kouzmanov, L. Bindi, D. Asael, Y. Fouquet, J. Etoubleau, G. Burgaud, M. Wälle // Chemical Geology. - 2016. - V. 438. - P. 36-57. URL: https://doi.org/ 10.1016/j.chemgeo.2016.05.021 (дата обращения 23.03.2018).

25. Corbett G. Anatomy of porphyry-related $\mathrm{Au}-\mathrm{Cu}-\mathrm{Ag}-\mathrm{Mo}$ mineralised systems: Some exploration implications // AIG Bulletin. 2009. - № 49. - P. 33-46.

26. Hedenquist J.W. Epithermal High Sulfidation Gold Deposits. URL: http://www.geologinesia.com/2015/11/epithermal-highsulfidation-gold_9.html (дата обращения 26.03.2018).

27. Mineralogy, alteration patterns, geochemistry, and fluid properties of the Ag-Au epithermal deposit Nová Baňa, Slovakia / J. Majzlan, K. Berkh, S. Kiefer, P. Kodera, A.E. Fallick, M. Chovan, F. Bakos, A. Biroň, Š. Ferenc, J. Lexa // Mineralogy and Petrology. - 2018. - V. 112. - Iss. 1. - P. 1-23. URL: https://doi.org/ $10.1007 /$ s00710-017-0516-0 (дата обращения 26.03.2018).

28. Precious metals assemblages at the Mikheevskoe porphyry copper deposit (South Urals, Russia) as proxies of epithermal overprinting / O.Y. Plotinskaya, O.B. Azovskova, S.S. Abramov, E.O. Groznova, K.A. Novoselov, R. Seltmann, J. Spratt // Ore Geology Reviews. - 2018. - V. 94. - P. 239-260. URL: https://doi.org/10.1016/j.oregeorev.2018.01.025 (дата обращения 26.03.2018).

29. Zhai D., Liu J. Gold-telluride-sulfide association in the Sandaowanzi epithermal Au-Ag-Te deposit, NE China: implications for phase equilibrium and physicochemical conditions // Mineralogy and Petrology. - 2014. - V. 108. - Iss. 6. - P. 853-871. URL: 
https://doi.org/10.1007/s00710-014-0334-6 (дата обращения 26.03.2018)

30. Yuningsih E.T., Matsueda H. Genesis and origin of Te-bearing gold-silver-base metal mineralization of the Arinem deposit in western Java, Indonesia // Journal of Mineralogical and Petrological Sciences. - 2014. - V. 109. - Iss. 2. - P. 49-61. URL: https://doi.org/10.2465/jmps.130118a (дата обращения 26.03.2018).

31. Physicochemical models of formation of gold-silver mineralization at the Rogovik deposit (Northeastern Russia) / T.V. Zhuravkova, G.A. Palyanova, K.V. Chudnenko, R.G. Kravtsova, I.R. Prokopyev, A.S. Makshakov, A.S. Borisenko // Ore Geology Reviews. 2017. - V. 91. - P. 1-20. URL: https://doi.org/10.1016/j.oregeorev.2017.10.017 (дата обращения 26.03.2018).
32. Gold-Silver mineralization in porphyry-epithermal systems of the Baimka trend, western Chukchi Peninsula, Russia / Yu.N. Nikolaev, I.A. Baksheev, V.Yu. Prokofiev, E.V. Nagornaya, L.I. Marushchenko, Yu.N. Sidorina, A.F. Chitalin, I.A. Kal'ko // Geology of Ore Deposits. - 2016. - V. 58. - № 4. - P. 284-307. DOI: $10.1134 / \mathrm{s} 107570151604005 \mathrm{x}$

33. Paleogene magmatism and gold metallogeny of the Jinping terrane in the Ailaoshan ore belt, Sanjiang Tethyan Orogen (SW China): Geology, deposit type and tectonic setting / J. Zhang, H. Wang, S. Li, T. Li // Ore Geology Reviews. - 2017. - V. 91. P. 620-637. URL: https://doi.org/10.1016/j.oregeorev.2017.08.032 (дата обращения 26.03.2018).

Поступила 04.04.2018 2.

\section{Информация об авторах}

Гусев А.И., доктор геолого-минералогических наук, профессор кафедры естественно-научных дисциплин, безопасности жизнедеятельности и туризма Алтайского государственного гуманитарно-педагогического университета имени В.М. Шукшина.

Taбакаева E.M., кандидат геолого-минералогических наук, научный сотрудник управления научно-исследовательской деятельности Алтайского государственного гуманитарно-педагогического университета имени B.M. Шукшина. 


\title{
MAGMATIZM AND EPITHERMAL Ag-Au ORE MINERALIZATION OF KRASNOYARSK GOLD ORE FIELD OF GORNY ALTAI
}

\author{
Anatoliy I. Gusev', \\ anzerg@mail.ru \\ Evgeniya M. Tabakaeva', \\ tabakaeva16@mail.ru \\ 'Shukshin Altai State Humanities Pedagogical University,
53, Vladimir Korolenko street, Biysk, 659333, Russia.
}

The relevance of the study is caused by the need of researching petrology, geochemistry subvolcanic rocks and epithermal Ag-Au ore mineralization of Krasnoyarsk ore field of Gorny Altai. Different types of ore mineralization: copper, cobalt, arsenic, tungstain and gold, are associated in space and paragenetic with subvolcanic stocks of granitoids. High sulfidation type of Ag-Au ore mineralization was researched first in Gorny Altai.

The main aim of the research is to study petrology, geochemical features of rocks and ore mineralization of Krasnoyarsk deposit using the experimental diagrams, which allow solving the genetic problems and revealing the physic-chemical features of petro- and oregenesis.

Methods. Elements were determined in rocks by inductively coupled plasma method on the mass spectrometer "OPTIMA-4300» in the Laboratory of Institute of mineralogy, geochemistry and crystallochemistry of rare elements (Moscow). Isotopes of sulfur and oxygen were determined on the mass-spectrometer MI 1201B in the same laboratory.

Results. Subvolcanic stocks of granitoids of the Middle Devonian of Korgonskiy complex are the main ore generating objects in Krasnoyarsk ore field. These granitoids are of the peraluminous type with varying contents of $\mathrm{Mg}$ and Fe. The tetrad effect of REE fractionation (W-type) is revealed in rocks. The contents of $A u$ and $A g$ in rocks increase with decreasing value of tetrad effect of $R E E$ fractionation (W-type). The deep magma chamber evolved toward increasing its level with the formation of sharply acid-sulfur characteristics and with the formation of near ore argillizites. Mineralization of the Krasnoyarsk deposit is represented by a series of nested quartz lodes with the formation of a kind of linear stockwork. Ores are formed in three stages: sulfidic, telluridic and postmineral. The main ore minerals are pyrite, galenite, sphalerite, tetrahedrite, tennantite, electrum, tetradymite, seldom - altaite, hessite, enargite, luzonite. The main minerals of lodes are quartz, calcite, chlorite, siderite, kaolinite, montmorillonite, illite. Gold content in ores changes from 0,5 to 29,6 ppm, silver - from 15 to 5000 ppm. Ratio of Ag/Au in ores is from 135 to 150. This indicates that the Krasnoyarsk deposit belongs to the Ag-Au type. The temperatures of homogenization of gas-liquid inclusions in quartz of different generations from stage to stage decreased from 265 to $175^{\circ} \mathrm{C}$. The sulfur fugacity decreased from the first stage (-10-11) to the second one (-15-16), fTe increased from $(-15)$ to $(-10)$ and $\mathrm{fO}_{2}$ increased from $(-39,5)$ to $(-37)$. Isotopes of sulfur and oxygen indicate a magmatic source for sulfur and meteoric for oxygen.

\section{Key words:}

Geochemistry, petrology, granitoids, stocks, tetrad effect fractionation of REE fractionation, lodes, lead, copper, gold, silver, fugacity of $\mathrm{S}_{2}, \mathrm{O}_{2}, \mathrm{Te}_{2}$.

The research was supported by the RFBR regional grant «Petrology of magmatism and genesis of ore-formation of KorgonKrasnoyarsk ore area in Altai region» (project no.18-45-220022, code and title of the contest: $p_{\text {_a }}$, regional contest of projects of fundamental researches).

\section{REFERENCES}

1. White N.C., Hedenquist J.W. Epithermal environments and styles of mineralization: Variations and their causes, and guidelines for exploration. Journal of Geochemical Exploration, 1990, vol. 36, no. 1-3, pp. 445-474. Available at: https://doi.org/ 10.1016/0375-6742(90)90063-G (accessed 23 March 2018).

2. Gusev N.I., Shokalskii S.P., Gusev A.I. The age of magmatism (U-Pb, SHRIMP II) controlling the epithermal mineralization of the Novofirsovsky gold ore cluster (Altai). Regional Geology and Metallogeny, 2011, no. 45, pp. 98-105. In Rus.

3. Anders E., Grevesse N. Abundances of the elements: meteoritic and solar. Geochimica et Cosmochimica Acta, 1989, vol. 53, no. 1, pp. 197-214. DOI: 10.1016/0016-7037(89)90286-X.

4. Maniar P.D., Piccoli P.M. Tectonic discrimination of granitoids. Geological Society of America Bulletin, 1989, vol. 101, no. 5, pp. 635-643. D0I: $10.1130 / 0016-7606(1989) 101<0635$ : TDOG $>2.3 . C 0 ; 2$.

5. Villaseca C., Barbero L., Herreros V. A re-examination of the typology of peraluminous granite types in intracontinental orogenic belts. Transactions of the Royal Society of Edinburgh: Earth
Sciences, 1998, vol. 89, no. 2, pp. 113-119. D0I: 10.1017/ S0263593300007045

6. Irber W. The lanthanide tetrad effect and its correlation with $\mathrm{K} / \mathrm{Rb}, \mathrm{Eu} / \mathrm{Eu} * \mathrm{Sr} / \mathrm{Eu}, \mathrm{Y} / \mathrm{Ho}$, and $\mathrm{Zr} / \mathrm{Hf}$ of evolving peraluminous granite suites. Geochimica et Cosmochimica Acta, 1999, vol. 63 , no. 3-4, pp. 489-508. DOI: 10.1016/S0016-7037(99) 00027-7. Available at: https://doi.org/10.1016/S0016-7037 (99)00027-7 (accessed 1 April 2018).

7. Gusev A.I. K geokhimii aktsessornogo pirita Koshrabadskogo massiva Zapadnogo Uzbekistana [To the geochemistry of accessory pyrite of the Koshrabad massif of Western Uzbekistan]. Aktualnye problemy geologii, geofiziki i metallogenii. Materialy konferentsii, posvyashchennoy 80-letiyu sozdaniya Instituta geologii i geofiziki i 105-letiyu so dnya rozhdeniya akademika Kh.M.Abdullaeva [Actual problems of geology, geophysics and metallogeny. Conference materials devoted to the $80^{\text {th }}$ anniversary of creation of the Institute of Geology and Geophysics and the $105^{\text {th }}$ anniversary of the birth of Academician H.M. Abdullaev]. Tashkent, 2017. pp. 229-232.

8. Vinogradov A.P. Average content of chemical elements in rocks. Geochemistry International, 1962, no. 7, pp. 555-571. In Rus. 
9. Wasson J.T., Kallemeyn G.W., Runcorn S.K., Turner G., Woolfson M.M. Compositions of chondrites. Philosophical Transactions of the Royal Society A: Mathematical, Physical \& Engineering Sciences, 1988, vol. 325 , no. 1587 , pp. 535-544. D0I: 10.1098/rsta.1988.0066. Available at: https://doi.org/10.1098/ rsta.1988.0066 (accessed 1 April 2018).

10. Meyer C., Hemiey J.J. Wall rock alteration. Geochemistry of Hydrothermal Ore Deposits Ed. by H.L. Barnes. New York, Holt, Rinehart and Winston, 1967. pp. 166-235.

11. Hedenquist J.W. Precious metal vein systems in the National District, Humboldt County, Nevada; discussion. Economic Geology, 1986, vol. 81, no. 4, pp. 1020-1023. Available at: https:// doi.org/ 10.2113/gsecongeo.81.4.1020 (accessed 23 March 2018).

12. Vartanyan S.S., Schepotev Yu.M., Zaytsev A.I., Bedarev N.P., Nikolaev Yu.N. Gold ore deposits of non-traditional types - the basis for strengthening the resource base in the gold mining areas of Altai. Ores and Metals, 2006, no. 3, pp. 5-13. In Rus.

13. Scott S.D., Barnes H.L. Sphalerite geothermometry and geobarometry. Economic Geology, 1971, vol. 66, no. 4, pp. 653-669. Available at: https://doi.org/10.2113/gsecongeo.66.4.653 (accessed 23 March 2018).

14. Afifi A.M., Kelly W.C., Essene E.J. Phase relations among tellurides, sulfides, and oxides; I, Thermochemical data and calculated equilibria. Economic Geology, 1988, vol. 83, no. 2, pp. 377-394. Available at: https://doi.org/10.2113/gsecongeo.83.2.377 (accessed 23 March 2018).

15. John D.A. Miocene and Early Pliocene epithermal gold-silver deposits in the Northern Great basin, Western United States: characteristics, distribution, and relationship to magmatism. Economic Geology, 2001, vol. 96, no. 8, pp. 1827-1853. Available at: https://doi.org/10.2113/gseconge0.96.8.1827 (accessed 23 March 2018).

16. Cameron M., Bagby W.C., Cameron K.L. Petrogenesis of Voluminous mid-Tertiary ignimbrites of the Sierra Madre Occidental, Chihuahua, Mexico. Contributions to Mineralogy and Petrology, 1980, vol. 74, no. 3, pp. 271-284. Available at: https://doi.org/ 10.1007/BF00371697 (accessed 23 March 2018).

17. Bagby W.C., Cameron K.L. Cameron M. Contrasting evolution of calc-alkalic volcanic and plutonic rocks of western Chihuahua, Mexico. Journal of Geophysical Research. Solid Earth, 1981, vol. 86, Iss. B11, pp. 10402-10410. Available at: https://doi.org/ 10.1029/JB086iB11p10402 (accessed 23 March 2018).

18. Moll E.J. Geochemistry and petrology of Mid-Tertiary ash flow tuffs from the Sierra el Virulento Area, eastern Chihuahua, Mexico. Journal of Geophysical Research. Solid Earth, 1981, vol. 86, Iss. B11, pp. 10321-10334. Available at: https://doi.org/ 10.1029/JB086iB11p10321 (accessed 23 March 2018).

19. Bacon C.R., Macdonald R., Smith R.L., Baedecker P.A. Pleistocene high-silica rhyolites of the Coso Volcanic Field, Inyo County, California. Journal of Geophysical Research. Solid Earth, 1981, vol. 86, Iss. B11, pp. 10223-10241. Available at: https:// doi.org/10.1029/JB086iB11p10223 (accessed 23 March 2018).

20. Hildreth W. Gradients in silicic magma chambers: Implications for lithospheric magmatism. Journal of Geophysical Research. Solid Earth, 1981, vol. 86, Iss. B11, pp. 10153-10192. Available at: https://doi.org/10.1029/JB086iB11p10153 (accessed 23 March 2018).

21. Sillitoe R.H., Hedenquist J.W. Linkages between Volcanotectonic Settings, Ore-Fluid Compositions and Epithermal Pressious Metal Deposits. Society of Economic Geologists. Special Publication, 2003, vol. 10, pp. 315-343.

22. Barbarin B. A review of the relationships between granitoid types, their origins and their geodynamic environments. Lithos,
1999, vol. 46, no. 3, pp. 605-626. Available at: https:// doi.org/10.1016/S0024-4937(98)00085-1 (accessed 23 March 2018).

23. Cooke D.R., Simmons S.F. Characteristics and genesis of epithermal gold deposits. Reviews in Economic Geology, 2000, vol. 13, pp. 221-244.

24. Dekov V.M., Rouxel 0., Kouzmanov K., Bindi L., Asael D., Fouquet Y., Etoubleau J., Burgaud G., Wälle M. Enargite-luzonite hydrothermal vents in Manus Back-Arc Basin: submarine analogues of high-sulfidation epithermal mineralization. Chemical Geology, 2016, vol. 438, pp. 36-57. Available at: https://doi.org/ 10.1016/j.chemgeo.2016.05.021 (accessed 23 March 2018).

25. Corbett G. Anatomy of porphyry-related $\mathrm{Au}-\mathrm{Cu}-\mathrm{Ag}-\mathrm{Mo}$ mineralised systems: Some exploration implications. AIG Bulletin, 2009, no. 49 , pp. $33-46$.

26. Hedenquist J.W. Epithermal High Sulfidation Gold Deposits. Available at: http://www.geologinesia.com/2015/11/epithermal-high-sulfidation-gold 9.html (accessed 26 March 2018).

27. Majzlan J., Berkh K., Kiefer S., Kodëra P., Fallick A.E., Chovan M., Bakos F., Biroň A., Ferenc Š., Lexa J. Mineralogy, alteration patterns, geochemistry, and fluid properties of the Ag-Au epithermal deposit Nová Baňa, Slovakia. Mineralogy and Petrology, 2018, vol. 112, no. 1, pp. 1-23. Available at: https://doi.org/ 10.1007/s00710-017-0516-0 (accessed 26 March 2018).

28. Plotinskaya 0.Y., Azovskova 0.B., Abramov S.S., Groznova E.0., Novoselov K.A., Seltmann R., Spratt J. Precious metals assemblages at the Mikheevskoe porphyry copper deposit (South Urals, Russia) as proxies of epithermal overprinting. Ore Geology Reviews, 2018, vol. 94, pp. 239-260. Available at: https:// doi.org/ 10.1016/j.oregeorev.2018.01.025 (accessed 26 March 2018).

29. Zhai D., Liu J. Gold-telluride-sulfide association in the Sandaowanzi epithermal $\mathrm{Au}-\mathrm{Ag}$-Te deposit, NE China: implications for phase equilibrium and physicochemical conditions. Mineralogy and Petrology, 2014, vol. 108, no. 6, pp. 853-871. Available at: https://doi.org/10.1007/s00710-014-0334-6 (accessed 26 March 2018).

30. Yuningsih E.T., Matsueda H. Genesis and origin of Te-bearing gold-silver-base metal mineralization of the Arinem deposit in western Java, Indonesia. Journal of Mineralogical and Petrological Sciences, 2014, vol. 109, no. 2, pp. 49-61. DOI: https://doi.org/10.2465/jmps.130118a

31. Zhuravkova T.V., Palyanova G.A., Chudnenko K.V., Kravtsova R.G., Prokopyev I.R., Makshakov A.S., Borisenko A.S. Physicochemical models of formation of gold-silver mineralization at the Rogovik deposit (Northeastern Russia). Ore Geology Reviews, 2017, vol. 91, pp. 1-20. Available at: https://doi.org/10.1016/ j.oregeorev.2017.10.017 (accessed 26 March 2018).

32. Nikolaev Yu.N., Baksheev I.A., Prokofiev V.Yu., Nagornaya E.V., Marushchenko L.I., Sidorina Yu.N., Chitalin A.F., Kal'ko I.A. Gold-Silver mineralization in porphyry-epithermal systems of the Baimka trend, western Chukchi Peninsula, Russia. Geology of Ore Deposits, 2016, vol. 58, no. 4, pp. 284-307. D0I: $10.1134 / \mathrm{s} 107570151604005 \mathrm{x}$

33. Zhang J., Wang H., Li S., Li T. Paleogene magmatism and gold metallogeny of the Jinping terrane in the Ailaoshan ore belt, Sanjiang Tethyan Orogen (SW China): Geology, deposit type and tectonic setting. Ore Geology Reviews, 2017, vol. 91, pp. 620-637. Available at: https://doi.org/10.1016/j.oregeorev.2017.08.032 (accessed 26 March 2018).

Received: 4 April 2018.

\section{Information about the authors}

Anatoliy I. Gusev, Dr. Sc., professor, Shukshin Altai State Humanities Pedagogical University.

Evgeniya M. Tabakaeva, Cand. Sc., researcher, Shukshin Altai State Humanities Pedagogical University. 